\title{
Tuning zeolite properties for highly efficient synthesis of propylene from methanol
}

\author{
Ana Palčić, ${ }^{\mathrm{a}, \mathrm{b}}$ Vitaly V. Ordomsky, ${ }^{\mathrm{c} *}$ Zhengxing Qin ${ }^{\mathrm{a}}$, Veselina Georgieva, ${ }^{\mathrm{a}}$ Valentin Valtchev, ${ }^{\mathrm{a}, \mathrm{d} *}$ \\ aENSICAEN, UNICAEN, CNRS, Laboratoire Catalyse et Spectrochimie, Boulevard Maréchal Juin \\ 6, 14000 Caen, France.

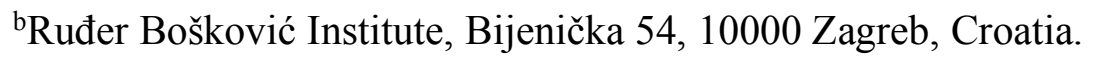 \\ 'Univ. Lille, CNRS, Centrale Lille, ENSCL, Univ. Artois, UMR 8181 - UCCS - Unité de Catalyse \\ et Chimie du Solide, F-59000 Lille, France. \\ ${ }^{\mathrm{d} S t a t e}$ Key Lab of Inorganic Synthesis \& Preparative Chemistry, Jilin University, Changchun \\ 130012, China.
}

*Valentin.Valtchev@ensicaen.fr, Vitaly.Ordomsky@univ-lille1.fr

\begin{abstract}
Series of nanosized ZSM-5 samples is synthesized at $170{ }^{\circ} \mathrm{C}, 150{ }^{\circ} \mathrm{C}, 120^{\circ} \mathrm{C}$ and $100{ }^{\circ} \mathrm{C}$. Experimental data show that the decrease of crystallization temperature leads to significant changes in zeolite properties. Crystals synthesized at $100{ }^{\circ} \mathrm{C}$ exhibit many framework defects with lower acid sites density, strength and larger external surface area. The selectivity to light olefins and the propylene-to-ethylene ratio increases as the crystallization temperature decreases. Propylene-toethylene ratio above 6 with the highest selectivity to propylene of $53 \%$ is obtained over ZSM-5 catalyst prepared at $100{ }^{\circ} \mathrm{C}$. Stability of the nanosized zeolite in MTO is also improved compared to industrial sample with similar $\mathrm{Si} / \mathrm{Al}$ ratio. This catalytic performance is a result of the decrease in the acid sites density, strength and the crystals' size, providing shorter diffusion path and larger external surface area. The presence of structural defects and different external surface are of the crystals has been shown to play an important role in the MTO catalyst performance.
\end{abstract}

KEYWORDS: zeolite ZSM-5; MTO; propylene; acidity; catalyst design 


\section{Introduction}

The design of catalysts having required performance in terms of activity and selectivity to valuable products represents nowadays one of the main issues in the heterogeneous catalysis. Zeolites are one of the most widely used solid heterogeneous catalysts due to their unique properties. Amongst the others the methanol transformations to hydrocarbons (MTH) developed in Mobil is one of the very important reactions over zeolite catalysts. ${ }^{[1]}$ This process has been modified further into methanol to olefins (MTO) by UOP, methanol to propylene (MTP) by Lurgi and methanol to gasoline (MTG) by Mobil. ${ }^{[2-4]}$ There are some drawbacks in the mentioned processes and further improvements are required according to the prevailing needs of the market. In the past several years there has been a significant increase of the light olefins demand and this trend continues to grow. Particularly, there is a higher market demand for propylene. To overcome this propylene shortage the existing processes are revised in order to bust the propylene selectivity.

Two zeolite catalysts are commonly applied in MTH processes: a silicoaluminophosphate with CHA-type structure (SAPO-34) and an aluminosilicate with MFI-type framework topology (ZSM5). On account of its small pore windows and mild acid strength, SAPO-34 catalyst exhibits excellent performance in production of light olefins, but deactivates quickly due to accumulation of carbonaceous residues (coke) ${ }^{[5]}$ On the other hand, the deactivation rate of ZSM-5 is significantly slower and the yield of light olefins is lower. ${ }^{[6]}$ The engineering of these two catalysts is still a challenging task.

In order to enhance the light olefins yield over ZSM-5 various approaches have been employed. For instance, post-synthesis modifications were used to increase the steric constraints and to achieve a favorable density and strength of Brønsted acid sites. ${ }^{[7-9]}$ In the early study of Chang et al. the ratio of propylene/ethylene (P/E) of 4.9 has been reached for the sample with $\mathrm{SiO}_{2} / \mathrm{Al}_{2} \mathrm{O}_{3}$ ratio $1670 .{ }^{[10]}$ In general, propylene selectivity was rising with decreasing zeolite acidity. The same effect of increase of the propylene to ethylene ratio and selectivity to light olefins has been observed by Prinz and Riekert over ZSM-5 catalysts with high Si/Al ratio. ${ }^{[11]}$ At low conversion (< $70 \%$ ) the selectivity for light olefins was found to be higher for smaller crystals. Moreover, relatively more propylene is generated on smaller than on the larger crystals. In addition, smaller ZSM-5 crystals showed longer catalyst lifetime in MTG reaction. ${ }^{[12]}$ Propylene selectivity of $42.2 \%$ and P/E ratio of 10 was achieved over high-silica ZSM-5 with mesopores generated by alkaline desilication. ${ }^{[13]}$ Such performance has been explained by enhanced diffusion and low number of Brønsted acid sites. Likewise, propylene to ethylene ratio close to 5 was obtained over fluoride medium synthesized ZSM-5 catalyst. ${ }^{[14]}$ Propylene selectivity rising from 16 to $52 \%$ and P/E ratio from 2 to 6.5 was achieved in a series of ZSM- 5 catalysts having Si/Al from 12 to $360 .{ }^{[15]}$ 
Modification of one of the samples by phosphorous resulted in improved propylene selectivity of $56 \%$ and propylene to ethylene ratio 7 . The effect has been ascribed to elimination of some acid sites upon P modification. Furthermore, propylene selectivity of $45 \%$ and P/E of 16 was obtained over ZSM-5 modified by zirconium oxide and phosphoric acid. ${ }^{[16]}$ Herein, the number of acid sites has increased while their strength becomes weaker. Besides, the pore size shrinks slightly. The selective production of propylene from methanol has been observed over ferrosilicate with MFItype topology (Fe-MFI) with small crystal sizes. ${ }^{[17]}$ The best propylene selectivity of $48 \%$, in conjunction with a high propene/ethene ratio of 11.5 has been attained.

The addressed findings demonstrate the impact of physicochemical properties of zeolite on the catalysts stability and selectivity. It was possible to obtain high selectivities, mainly by decrease of the amount of acid sites, substitution of Al for Fe or by doping of zeolite leading to decrease of the number and strength of acid sites. Zeolite doping has a positive effect, but leads to decrease of the pore volume and sometimes accelerates catalyst deactivation. Moreover, the Fe-counterpart of ZSM-5 is not stable in the presence of water. It is well established that the higher amount of acid sites and higher acid site density is often the reason of fast catalyst deactivation in MTO process. ${ }^{[18]}$ Hence, the best catalyst for the synthesis of propylene from methanol on the basis of literature results would be nanosized ZSM-5 crystals with lower acid sites density. Nanocrystal ZSM-5 zeolites have been already reported as efficient catalysts in comparison with micron sized counterparts in different catalytic reactions in terms of stability and selectivity. ${ }^{[19-21]}$

Among different strategies in preparing nanosized zeolites, clear sols are most often used due to the homogeneity of the system which results in crystalline product with narrow particle size distribution. ${ }^{[22]}$ Besides the gel composition the conditions of synthesis have a direct impact on the end product properties. ${ }^{[23,24]}$ Reaction temperature is one of the mostly varied parameters when engineering the materials. Generally, the nucleation is favored over the crystal growth at low temperatures. In consequence, smaller crystals are obtained. ${ }^{[20,22,24]}$ Lowering the reaction temperature in ZSM-5 synthesis was found to affect the crystallinity, morphology and chemical composition of zeolite crystals. ${ }^{[25,26]}$ Therefore, the decrease of the zeolite synthesis temperature might provide additional opportunities for adjusting the materials properties required for a particular application.

In the present work, we study the influence of the temperature of crystallization of nanosized ZSM5 on the materials features and subsequently its performance in the MTO reaction. The principle aim is to provide stable aluminosilicate zeolite catalyst in MTO reaction with high selectivity toward propene and therefore develop a simple strategy to design more efficient catalysts. 


\section{Results and Discussion}

\section{General characterization of zeolite samples}

Powder X-ray diffraction patterns of synthesized solids exhibit the diffraction peaks characteristic of MFI-type material (Figure 1). Slight increase in the peak intensities with rising of the synthesis temperature was observed. The relative crystallinity of the samples (Table 1) was determined applying method established in the literature, where the peak area in the XRD pattern of the samples in the range $22-25^{\circ} 2 \vartheta$ is compared with the peak area of the reference sample. ${ }^{[12,26]}$ Herein the ZSM-5(ind) sample was taken as a reference. The obtained values indicate that relative crystallinity gets lower with the decrease of the synthesis temperature. Such observation is in

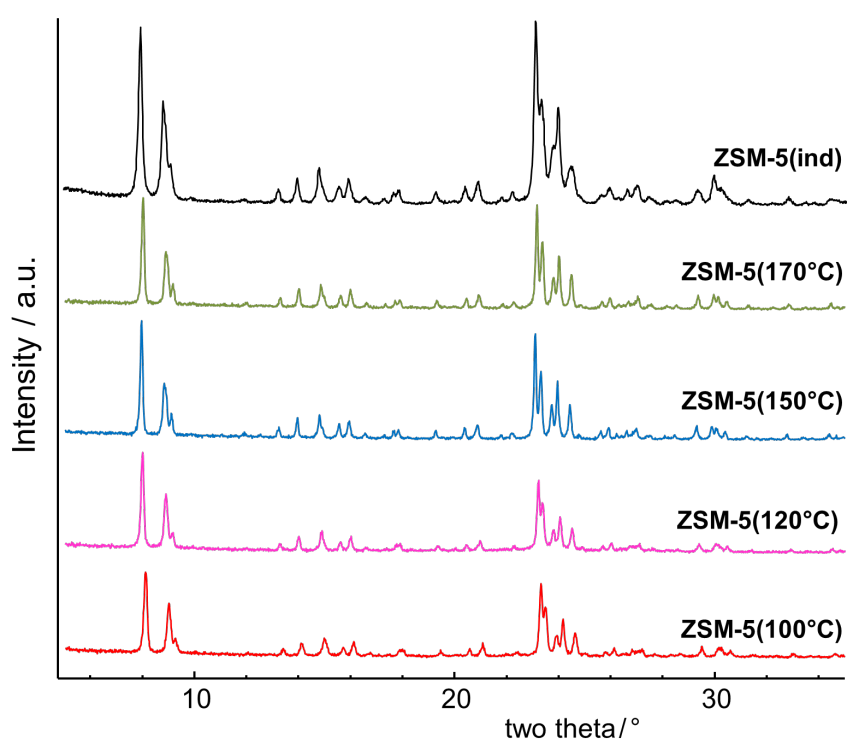

Figure 1. XRD patterns of the industrial and nanosized zeolites prepared at different crystallization temperatures.

agreement with the previously reported data on both conventional and seeded synthesis of ZSM5. ${ }^{[26,27]}$ The crystallinity of the samples prepared at elevated temperatures $\left(150^{\circ} \mathrm{C}\right.$ and $\left.170^{\circ} \mathrm{C}\right)$ is higher in respect to their counterparts prepared at $120^{\circ} \mathrm{C}$ and $100^{\circ} \mathrm{C}$ (Table 1).

Representative SEM images of the studied samples show that they exhibit the morphology typical of MFI crystals, some of them having very rough surface (Figure 2). A closer look reveals that the particles are composed of smaller crystallites. The TEM inspection of the ZSM-5 $\left(100^{\circ} \mathrm{C}\right)$ reveals that the particles are built of randomly oriented very small crystallites resulting in corrugated outline. The surface of ZSM-5 $\left(120^{\circ} \mathrm{C}\right)$ is also fairly rough due to the small size of building particles. High temperature samples $\left(150^{\circ} \mathrm{C}\right.$ and $\left.170^{\circ} \mathrm{C}\right)$ exhibit less rough surface, i.e., there are fewer intergrown crystals. 

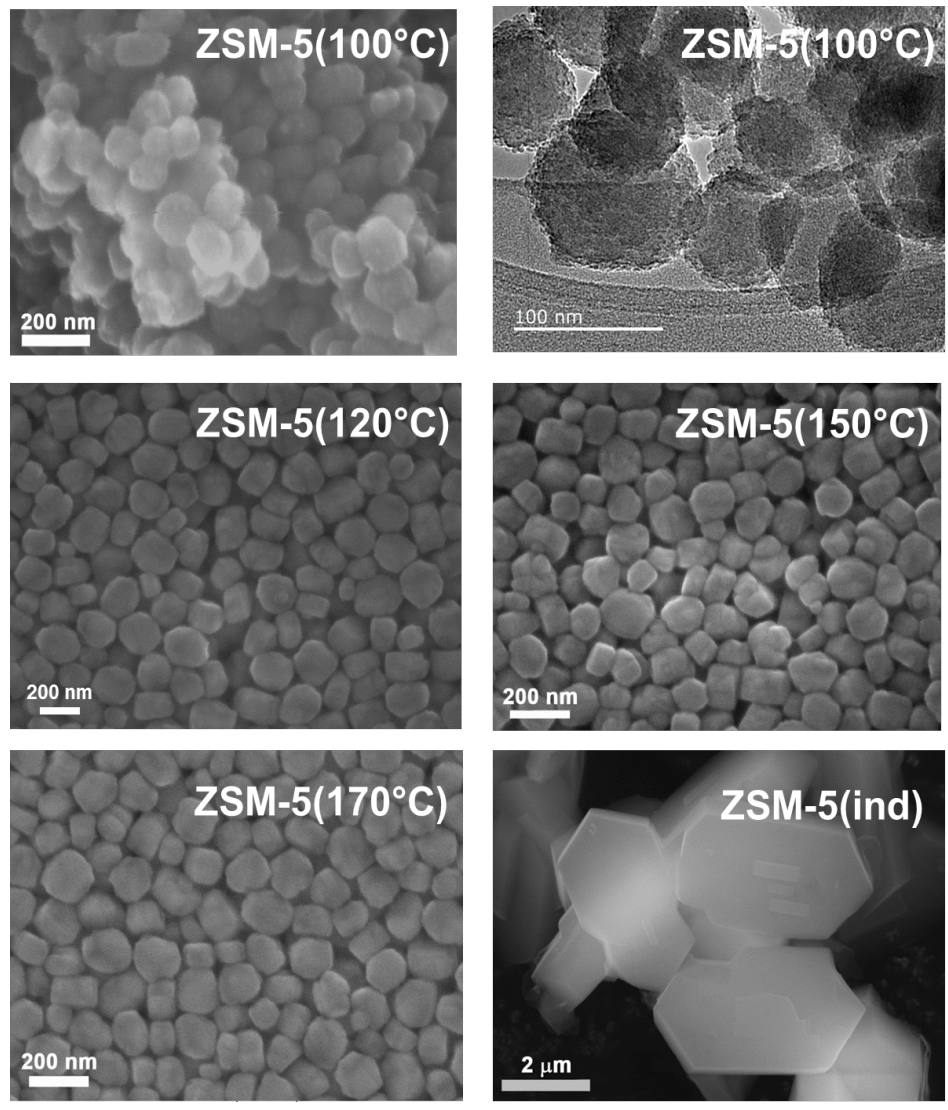

Figure 2. SEM (left) and TEM (right) micrographs of the $\mathrm{ZSM}-5\left(100^{\circ} \mathrm{C}\right)$ sample (the first line). SEM micrographs of the nanosized zeolites prepared at different crystallization temperatures and the industrial ZSM-5 (the second and the third line).

The particle size in each sample was determined as the average of the size of 90 measured particles (Table 1). The size of the nanosized ZSM-5 samples is ranging from 100 to $140 \mathrm{~nm}$. They are getting slightly larger with increasing the synthesis temperature. As known a lower crystallization temperature favors the nucleation and thus larger number of crystallites is formed in the system, which leads to smaller ultimate particles. The reaction temperature influences also the solubility of $\mathrm{Al}$ and $\mathrm{Si}$ species and accordingly the reaction kinetics. ${ }^{[22,27]}$ Consequently the concentration of reactive species in the liquid phase is inferior at lower crystallization temperature. The diffusion rate is also lower at low crystallization temperature. Combining these phenomena implies that the collisions/contacts between the reacting species is more frequent and more successful, i.e. leads to the formation of viable entities able to grow further and subsequently form a crystalline product, at a higher temperature. Briefly, at elevated temperature the growth rate is higher and the obtained crystals larger. As a result the crystallization of a particular initial system at different temperature leads to ZSM-5 particles having different levels of aggregation and crystallinity degree. 
Nevertheless, all synthesized products in this study were with nanosize dimensions, much smaller of the industrial sample which exhibits well shaped crystals with size 3-5 $\mu \mathrm{m}$ (Figure 2).

Table 1. Framework composition, size and porosity of the studied ZSM-5 samples.

\begin{tabular}{lcccccccc}
\hline \multicolumn{1}{c}{ Sample } & $\begin{array}{c}\text { Relative } \\
\text { crystallinity } \\
\%\end{array}$ & $\mathrm{Si} / \mathrm{Al}^{\mathrm{ICP}}$ & $\mathrm{Si} / \mathrm{Al}^{\mathrm{NMR}}$ & $\begin{array}{c}\mathrm{Size} \\
\mathrm{nm}\end{array}$ & $\begin{array}{c}S_{\mathrm{BET}} \\
\mathrm{m}^{2} \mathrm{~g}^{-1}\end{array}$ & $\begin{array}{c}V_{\text {mic }} \\
\mathrm{cm}^{3} \mathrm{~g}^{-1}\end{array}$ & $\begin{array}{c}S_{\text {ext }} \\
\mathrm{m}^{2} \mathrm{~g}^{-1}\end{array}$ & $\begin{array}{c}V_{\text {total }} \\
\mathrm{cm}^{3} \mathrm{~g}^{-1}\end{array}$ \\
\hline ZSM-5(ind) & 100 & 25 & 27 & 4000 & 377 & 0.180 & 2 & 0.200 \\
ZSM-5 $\left(170^{\circ} \mathrm{C}\right)$ & 86 & 27 & 36 & 135 & 391 & 0.175 & 36 & 0.399 \\
ZSM-5 $\left(150^{\circ} \mathrm{C}\right)$ & 87 & 31 & 35 & 128 & 389 & 0.177 & 32 & 0.371 \\
ZSM-5 $\left(120^{\circ} \mathrm{C}\right)$ & 72 & 25 & 37 & 116 & 388 & 0.147 & 72 & 0.523 \\
ZSM-5 $\left(100^{\circ} \mathrm{C}\right)$ & 71 & 35 & 46 & 103 & 428 & 0.142 & 107 & 0.548 \\
\hline
\end{tabular}

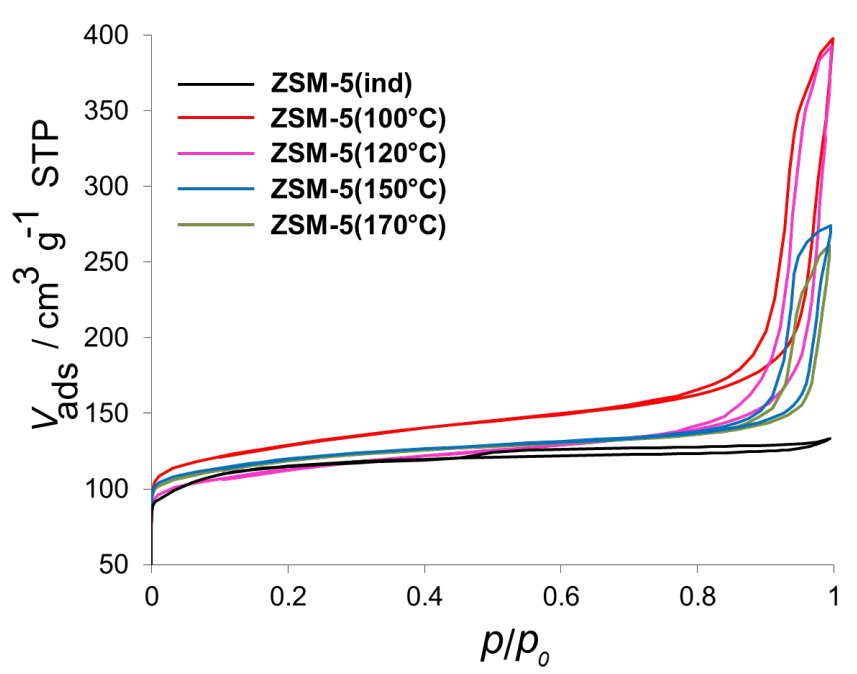

Figure 3. Nitrogen adsorption/desorption isotherms of the industrial and nanosized zeolites prepared at different crystallization temperatures.

The porosity and specific surface area of the zeolite samples were determined by nitrogen adsorption/desorption measurements. The obtained isotherms are depicted in Figure 3. The industrial sample, ZSM-5(ind), exhibits classical Type I adsorption isotherm with a sharp uptake at low relative pressures followed by horizontal adsorption and desorption branches. On the other hand, nanosized ZSM-5 samples display a mixed Type I and Type IV isotherm with a very steep and almost parallel hysteresis (H1 type) in the range $p / p_{0}>0.8$. This is related to pores comprised of tightly packed, nearly uniform, particles. Micropore volumes of the samples prepared at 150 and $170{ }^{\circ} \mathrm{C}$ are very close to those characteristic of highly crystalline MFI-type material. In contrast, lower values of micropore volume of the ZSM-5 $\left(100^{\circ} \mathrm{C}\right)$ and ZSM-5 $\left(120^{\circ} \mathrm{C}\right)$ samples imply lower crystallinity and the presence of certain amount of dense amorphous phase. The sample prepared at 
$120{ }^{\circ} \mathrm{C}$ shows $S_{\text {ext }} 72 \mathrm{~m}^{2} / \mathrm{g}$, while 150 and $170{ }^{\circ} \mathrm{C}$ samples have $S_{\text {ext }}$ of $32 \mathrm{~m}^{2} / \mathrm{g}$ and $36 \mathrm{~m}^{2} / \mathrm{g}$, respectively. The highest external surface area of ZSM- $\left(100^{\circ} \mathrm{C}\right)$ is obviously due to the smallest particle size (Table 1) and rough surface which arises from very small randomly oriented crystalline domains. The size of the individual crystallites building the particles can be seen on the TEM image shown in Figure 2 (top, right). The sample ZSM-5 $\left(120^{\circ} \mathrm{C}\right)$ also exhibits rough surface, but the size of individual crystals is larger than in the $100{ }^{\circ} \mathrm{C}$ sample. There is a significant contribution of mesopores to the total pore volume of the nanosized materials, which has already been reported in the literature. ${ }^{[28]}$ This phenomenon is more pronounced in the samples prepared at low temperatures where the crystallites are smaller. BJH analysis reveals that the size of mesopores for all studied nanosized samples is in the range $20-50 \mathrm{~nm}$. These relatively large pores are due to intra-particle porosity.

\section{Characterization of acid sites}

${ }^{27} \mathrm{Al}$ MAS NMR is a standard tool in determining the environment of aluminum atoms in zeolite samples. ${ }^{27} \mathrm{Al}$ MAS NMR spectrum of fully hydrated industrial sample exhibits a sole resonance at $56 \mathrm{ppm}$ corresponding to tetrahedrally coordinated aluminium in zeolite framework (Figure 4). The spectra of nanosized samples are more complex. The peak of tetrahedrally coordinated Al is much broader and asymmetric, in addition the presence of penta- (ca. $30 \mathrm{ppm}$ ) and octahedrally (ca. 0 ppm) coordinated $\mathrm{Al}$ is detected (Figure 4). The concentration of later species is higher in the samples synthesized at $100{ }^{\circ} \mathrm{C}$ and $120{ }^{\circ} \mathrm{C}$. In general, the integrated NMR signal intensities are proportional to the number of nuclei contributing to the signal and the spectra are expected to be quantitative. In spite having very similar bulk $\mathrm{Al}$ content $\left(\mathrm{Si} / \mathrm{Al}{ }^{\mathrm{ICP}}\right.$ ) in nanosized samples (Table 1), the total intensity of the signal in the spectra of zeolites crystallized at higher temperature (150 and $\left.170{ }^{\circ} \mathrm{C}\right)$ is stronger than that the lower temperatures counterparts $\left(100\right.$ and $\left.120{ }^{\circ} \mathrm{C}\right)$. This effect might be attributed to the increase of the contribution of "NMR invisible Al species" in the samples prepared at lower temperatures. ${ }^{[29,30]}$ The high quadrupolar moment might make their NMR signal too broad and thus some species cannot be detected.

To get more detailed information of the exact positions of the peaks and the contributing species, the spectra were decomposed using dmfit analysis software. ${ }^{[31]}$ For each sample four resonances were observed. The industrial sample exhibits resonance at $56 \mathrm{ppm}$ corresponding to framework tetrahedral aluminum atoms. The peak shifts upfield (53 ppm) for the nanosized samples. These features have been earlier explained by different siting of $\mathrm{Al}$ atoms in the framework $\mathrm{T}$ sites. ${ }^{[32,33]}$ The Al should be localized preferentially in the sites with low Al-O distances and T-O-T angles in the case of industrial sample and less constrained positions for the nanosized zeolite samples. Furthermore, a signal arising from extra-framework octahedral $\mathrm{Al}$ at about $0 \mathrm{ppm}$ is found in all 
nanosized zeolites. Octahedral Al moieties give rise to one more signal in ${ }^{27}$ Al MAS NMR spectra of all synthesized samples but at different positions. Resonances at 7 and 4 ppm are detected in the samples ZSM-5 $\left(100^{\circ} \mathrm{C}\right)-\mathrm{ZSM}-5\left(120^{\circ} \mathrm{C}\right)$ and ZSM-5 $\left(150^{\circ} \mathrm{C}\right)-\mathrm{ZSM}-5\left(170^{\circ} \mathrm{C}\right)$, respectively. Extraframework Al may be present in zeolites in different forms as cations or neutral species occupying various positions in the micropores. ${ }^{[34-36]}$ It appears that polymeric octahedral Al species (amorphous phase) have resonances at lower field than the monomeric moieties since in a cluster the nuclei get more deshielded. ${ }^{[37-39]}$ Hence, on the grounds of the positions of the signals in ${ }^{27} \mathrm{Al}$ MAS NMR spectra it can be deduced that low temperature samples ( 7 ppm signal) have higher content of six-fold coordinated Al species built of several Al atoms (polymerized Al species) than the samples prepared at $150^{\circ} \mathrm{C}$ and $170{ }^{\circ} \mathrm{C}(4 \mathrm{ppm}$ signal $)$.

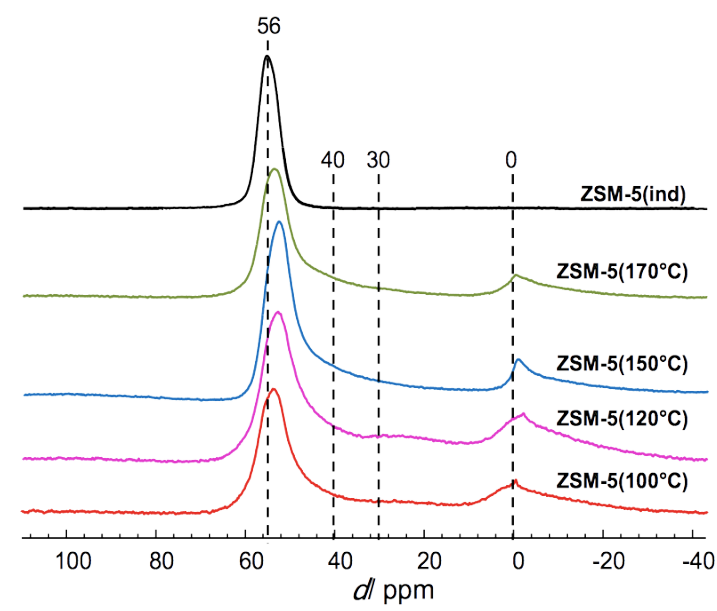

Figure 4. ${ }^{27} \mathrm{Al}$ MAS NMR spectra of the industrial and nanosized zeolites prepared at different crystallization temperatures.

In the ${ }^{27} \mathrm{Al}$ MAS NMR spectrum of each nanosized sample there is a broad signal appearing in the region 20-40 ppm. According to the spectra decomposition, in the samples ZSM-5 $\left(100^{\circ} \mathrm{C}\right)$ and ZSM-5 $\left(120^{\circ} \mathrm{C}\right)$ there is a signal at $29 \mathrm{ppm}$. On the other hand, samples ZSM-5 $\left(150^{\circ} \mathrm{C}\right)$ and ZSM$5\left(170^{\circ} \mathrm{C}\right)$ exhibit resonance further downfield at $38 \mathrm{ppm}$. Such large difference in the signals position indicates distinct coordination of oxygen atoms around Al species contributing to these resonances. The peaks in the 30-50 ppm region have often been found in the ${ }^{27} \mathrm{Al}$ MAS NMR spectra of MFI structure after steaming due to the partial release of framework Al atoms. ${ }^{[40,41]}$ Typically perturbed four-fold coordinated or five-fold coordinated aluminium species generate signals in this region. In general, signals around $30 \mathrm{ppm}$ in the ${ }^{27} \mathrm{Al}$ MAS NMR spectra are perceived to stem from extra-framework five-fold coordinated Al moieties, ${ }^{[42,43]}$ while the 
resonances at higher chemical shift positions emanate from less ordered framework $\mathrm{Al}$ atoms present in not-fully crystalline zeolites. ${ }^{[4]}$ Thus, it can be concluded that the high temperature samples encompass highly distorted tetrahedral Al species (38 ppm signal) while low temperature samples involve five-fold coordinated Al (29 ppm signal). Thus the ${ }^{27} \mathrm{Al}$ NMR data indicate once again the presence of amorphous phase in the samples $\mathrm{ZSM}-5\left(100^{\circ} \mathrm{C}\right)$ and $\mathrm{ZSM}-5\left(120^{\circ} \mathrm{C}\right)$. Although less there is still a certain amount of perturbed and extra-framework $\mathrm{Al}$ in high temperature samples.

To further investigate the effects that occur with the decrease of the temperature of crystallization ${ }^{29} \mathrm{Si}$ MAS NMR measurements were performed (Figure 5). The main resonances appear in the range from $-110 \mathrm{ppm}$ to $-120 \mathrm{ppm}$ with two dominating signals at $-113 \mathrm{ppm}$ and $-115 \mathrm{ppm}$. In this range there is overlapping of several signals arising from $\mathrm{Si}$ atoms in the nonequivalent crystallographic $\mathrm{T}$ positions in MFI framework. They are characteristic for $\mathrm{Q}^{4}$ tetrahedral Si species (Si surrounded by

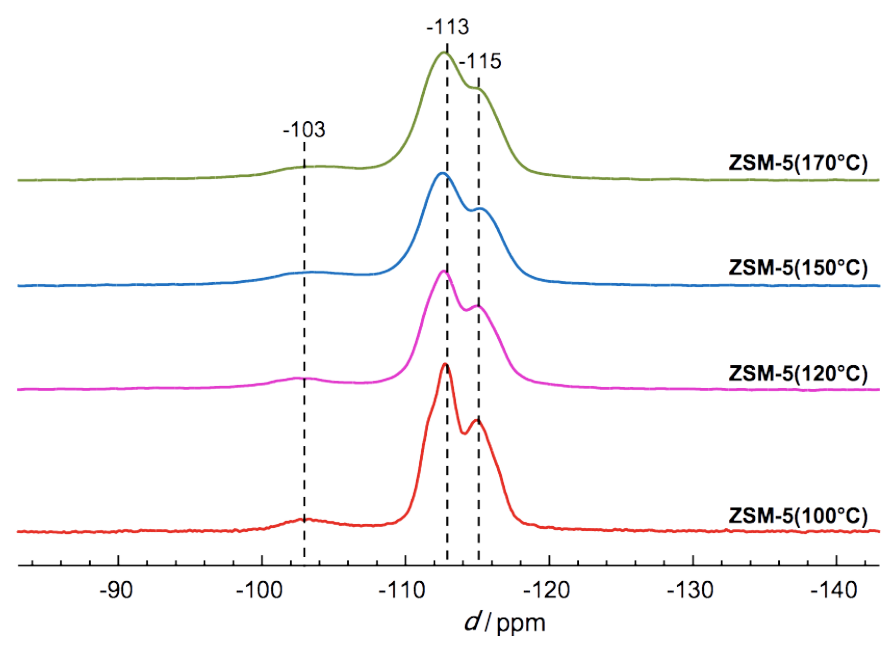

Figure 5. ${ }^{29}$ Si MAS NMR spectra of the nanosized zeolites prepared at different crystallization temperatures.

four other $\mathrm{Si}$ atoms - $\mathrm{Si}(4 \mathrm{Si})$ ). Absence of resolution is caused by the presence of defects and $\mathrm{Al}$ in the lattice. Namely, Al prompts certain distortion of the lattice leading to change of chemical shift which depends on the distance between $\mathrm{Al}$ and the $\mathrm{Q}^{4} \mathrm{Si}$ species. ${ }^{[45]}$ The band at $-103 \mathrm{ppm}$ is associated to $\mathrm{Q}^{3} \mathrm{Si}$ species, either $\mathrm{Si}(3 \mathrm{Si}, 1 \mathrm{Al})$ or $\mathrm{Si}(3 \mathrm{Si}, 1 \mathrm{OH}) .{ }^{[46]}$

The ${ }^{29} \mathrm{Si}\left\{{ }^{1} \mathrm{H}\right\}$ cross-polarization spectra plotted in Figure 6 were taken in order to study the silanol species in the samples. ${ }^{29} \mathrm{Si}\left\{{ }^{1} \mathrm{H}\right\} \mathrm{CP}$ NMR spectra are usually not quantitative since proton-rich species are often overemphasized. Two intense resonances, at $-103 \mathrm{ppm}$ and $-115 \mathrm{ppm}$ were 
observed in all samples. The resonance at $-103 \mathrm{ppm}$ is characteristic of $\mathrm{Si}(3 \mathrm{Si}, 1 \mathrm{OH})$ species, while the one at $-115 \mathrm{ppm}$ of $\mathrm{Si}(4 \mathrm{Si})$ with ${ }^{1} \mathrm{H}$ in the vicinity. These data show the presence of nest type silanol defects in the nanosized samples. The intensities of the resonances of $\mathrm{Si}(n \mathrm{Al})$ species in ${ }^{29} \mathrm{Si}$ MAS NMR spectra is often used to calculate the $\mathrm{Si} / \mathrm{Al}$ ratio in zeolites. ${ }^{[47]}$ The main drawback of

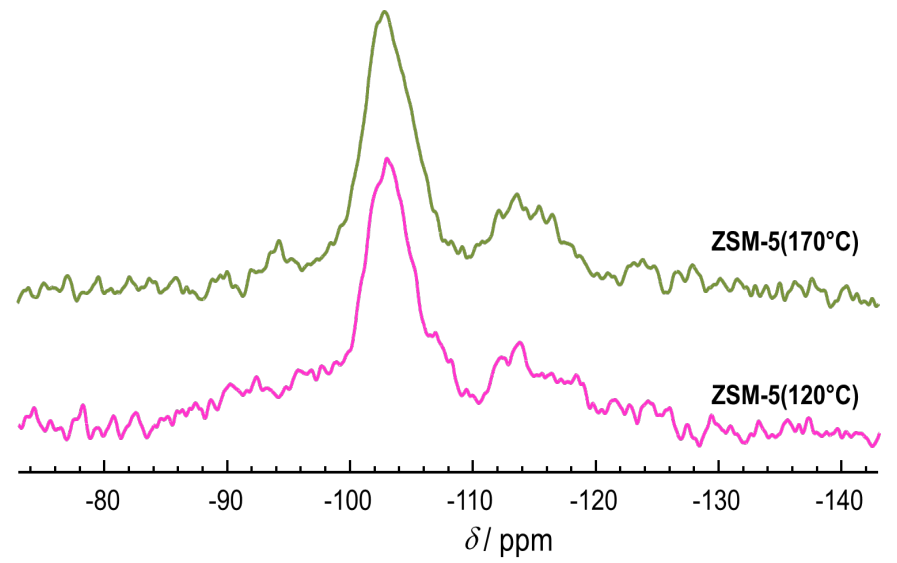

Figure 6. ${ }^{29} \mathrm{Si}\left\{{ }^{1} \mathrm{H}\right\}$ cross-polarization spectra of nanosized zeolites prepared at 120 and $170{ }^{\circ} \mathrm{C}$.

the method is the overlapping of $\mathrm{Si}(n \mathrm{Al})$ and $\mathrm{Si}(n \mathrm{OH})$ signals, consequently the calculated $\mathrm{Si} / \mathrm{Al}$ ratio value is usually lower than the actual one. Since the total sum of the intensities in the normalized ${ }^{29} \mathrm{Si}\left\{{ }^{1} \mathrm{H}\right\}$ CP NMR spectra of the studied samples is practically equal it can be assumed that the contribution of $\mathrm{Si}(3 \mathrm{Si}, 1 \mathrm{OH})$ moieties to the broad signal at $-103 \mathrm{ppm}$ in ${ }^{29} \mathrm{Si}$ NMR spectra is nearly identical in all of the samples. Hence the ${ }^{29} \mathrm{Si}$ NMR data can be used for calculation of framework Si/Al. Obtained values are listed in Table 1 (column $\mathrm{Si} / \mathrm{Al}^{\mathrm{NMR}}$ ). They are higher than the $\mathrm{Si} / \mathrm{Al}$ ratio determined by chemical analysis. In the case of samples prepared at 120,150 and $170{ }^{\circ} \mathrm{C}$ the $\mathrm{Si} / \mathrm{Al}$ ratio is very similar, approximately 36 , while for $\mathrm{ZSM}-5\left(100^{\circ} \mathrm{C}\right)$ is 46 . The different values of $\mathrm{Si} / \mathrm{Al}^{\mathrm{NMR}}$ when compared with bulk chemical analysis $\left(\mathrm{Si} / \mathrm{Al}^{\mathrm{ICP}}\right)$ are attributed to the presence of extra-framework Al species. This finding represents another indication on the presence of amorphous material and extra-framework $\mathrm{Al}$ in the samples.

The nature of hydroxyl groups was studied by FTIR spectroscopy. In Figure 7 are displayed the FTIR spectra of studied materials taken after their activation at $500{ }^{\circ} \mathrm{C}$ under high vacuum. The studied range is between $3800-3000 \mathrm{~cm}^{-1}$ which corresponds to stretching vibrations of hydroxyl groups. In this region five different features of the spectra can be observed. All samples exhibit a broad low intensity band in the range $3550-3500 \mathrm{~cm}^{-1}$. Generally this band is ascribed to silanol nests that consist of a certain number of silanol groups interacting through hydrogen bonding. These groups are usually situated at crystal steps or extended defects. ${ }^{[48,49]}$ This corroborates the finding from NMR where defects were detected as well. The low intensity of the band suggests relatively limited amount of such sites. 


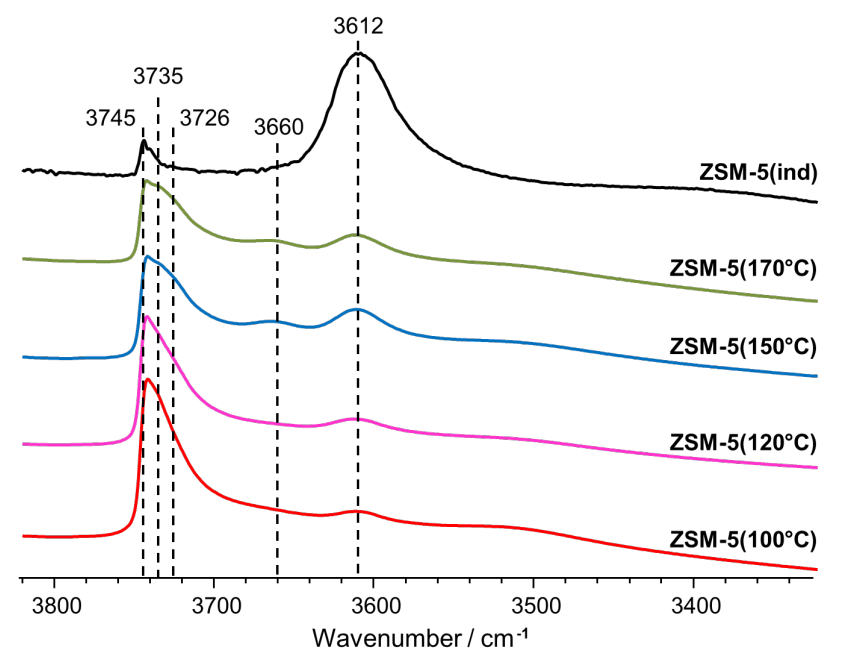

Figure 7. FTIR spectra in $\mathrm{OH}$ region of the industrial and nanosized zeolites synthesized at different crystallization temperatures.

The band at $3612 \mathrm{~cm}^{-1}$ is related to Brønsted acid sites, more precisely hydroxyl groups bridging $\mathrm{Si}$ and $\mathrm{Al}(\mathrm{Si}-\mathrm{OH}-\mathrm{Al}) \cdot{ }^{[48,49]}$ The intensity of this band for nanosized ZSM-5 samples is significantly lower than the reference ZSM-5(ind). The intensity of the band decreases with decrease of the temperature of crystallization. On the other hand, the nanosized zeolites exhibit a more intense band at about $3740 \mathrm{~cm}^{-1}$ in respect to the industrial sample. This band can be decomposed into three peaks at $3745 \mathrm{~cm}^{-1}, 3735 \mathrm{~cm}^{-1}$ and $3726 \mathrm{~cm}^{-1}$. They are assigned to isolated silanols at external surface, weakly interacting internal silanols possibly near structural defects (intracrystalline $\mathrm{Si}-\mathrm{OH}$ ) and internal silanols in zeolite channels, respectively. ${ }^{[48,50,51]}$ The contribution of different peaks varies in the set of nanosized samples. Thus, the peak at $3745 \mathrm{~cm}^{-1}$ is more intense for ZSM$5\left(100^{\circ} \mathrm{C}\right)$ and $\mathrm{ZSM}-5\left(120^{\circ} \mathrm{C}\right)$ due to the larger external surface area. ZSM-5 $\left(150^{\circ} \mathrm{C}\right)$ and ZSM$5\left(170^{\circ} \mathrm{C}\right)$ exhibit less intense and broader band owing to their lower external surface area and therefore higher contribution of internal silanol groups. As already mentioned, the most expressed feature in the spectra of ZSM-5(ind) corresponds to Brønsted acid sites $\left(3612 \mathrm{~cm}^{-1}\right)$ with very small impact of silanols. Such a marked difference between nanosized and micronsized ZSM-5 samples of comparable $\mathrm{Si} / \mathrm{Al}$ ratio was already reported. ${ }^{[48,52,53]}$ As mentioned, this feature of nanosized zeolites is due to the large external surface area and large amount of defects. The results of FTIR study are in line with the NMR data and confirm the large presence of hydroxyls in nanosized materials.

In the spectra of samples $\mathrm{ZSM}-5\left(150^{\circ} \mathrm{C}\right)$ and $\mathrm{ZSM}-5\left(170^{\circ} \mathrm{C}\right)$ is observed a weak band in the range $3645-3680 \mathrm{~cm}^{-1}$ which is usually assigned to tetrahedral $\mathrm{AlOH}$ groups partially attached to the framework. ${ }^{[25,26]}$ In these two samples a barely observable peak at $3780 \mathrm{~cm}^{-1}$ usually associated with 
octahedral extra-framework Al species was found. ${ }^{[54,55]}$ These features do not exist in the spectrum of the samples prepared at 100 and $120^{\circ} \mathrm{C}$. The result corroborates well with the assignments of ${ }^{27} \mathrm{Al}$ MAS NMR resonances. Namely, besides the framework Al the ZSM-5 $\left(150^{\circ} \mathrm{C}\right)$ and ZSM$5\left(170^{\circ} \mathrm{C}\right)$ samples exhibit highly distorted tetrahedral Al species not fully bound to the framework (IR 3645-3680 cm $\mathrm{cm}^{-1},{ }^{27} \mathrm{Al} \mathrm{NMR} 38 \mathrm{ppm}$ ) and octahedral extra-framework Al (IR $3780 \mathrm{~cm}^{-1},{ }^{27} \mathrm{Al}$ NMR 4 and $0 \mathrm{ppm})$. The samples ZSM-5 $\left(100^{\circ} \mathrm{C}\right)$ and ZSM-5 $\left(120^{\circ} \mathrm{C}\right)$ include mostly crystalline $\left({ }^{27} \mathrm{Al}\right.$ NMR $\left.53 \mathrm{ppm}\right)$ and some amorphous material with five- $\left({ }^{27} \mathrm{Al}\right.$ NMR $\left.29 \mathrm{ppm}\right)$ and six-fold $\left({ }^{27} \mathrm{Al}\right.$ NMR $\left.7 \mathrm{ppm}\right)$ coordination. It seems that amorphous aluminosilicate phase formed during low temperature crystallization does not contain a lot of $\mathrm{OH}$ groups since only zeolite framework bands were found in the corresponding IR spectra. ${ }^{[56]}$

The samples were further characterized by FTIR using pyridine as a probe molecule to discriminate between Brønsted and Lewis acid sites. In Figure 8 are depicted normalized IR spectra of zeolite samples with pyridine adsorbed at $150{ }^{\circ} \mathrm{C}$. They were normalized with respect to the mass of the self-supported disc of each sample. In the range of $1400-1700 \mathrm{~cm}^{-1}$, chemically adsorbed pyridine was revealed by the usual set of bands: two bands at 1545 and $1622 \mathrm{~cm}^{-1}$ assigned to pyridinium ion $\left(\mathrm{PyrH}^{+}\right)$, two bands at 1454 and $1637 \mathrm{~cm}^{-1}$ related to coordinatively adsorbed pyridine and the superposition of signals of the species adsorbed on Lewis and Brønsted sites at $1491 \mathrm{~cm}^{-1}$. The

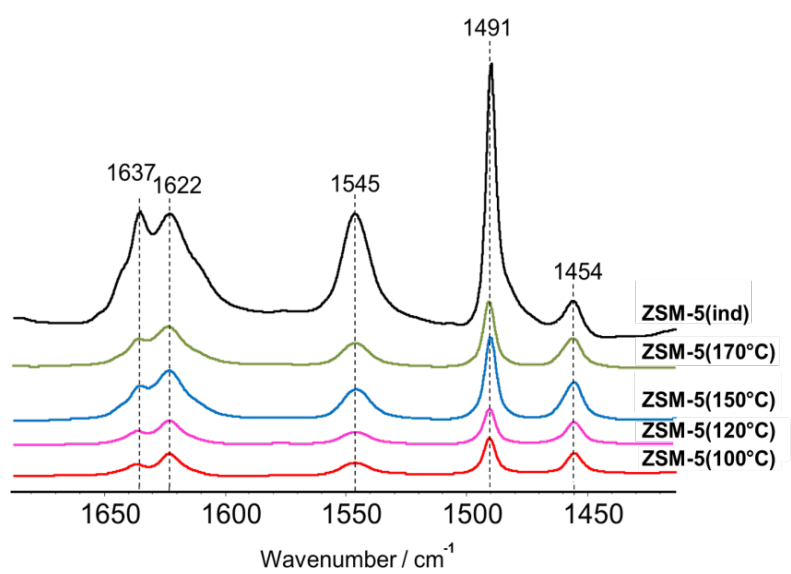

Figure 8. FTIR spectra after adsorption of Py over industrial and nanosized zeolites prepared at different crystallization temperatures.

concentrations of Brønsted (B) to Lewis (L) acid sites calculated based on published extinction coefficients for the bands at $1545 \mathrm{~cm}^{-1}$ and $1454 \mathrm{~cm}^{-1}$, are given in the Table 2 . The results suggest that nanosized samples have at minimum 3 times lower amount of Brønsted acid sites in comparison with industrial sample but similar amount of Lewis acid sites. The amount of Brønsted acid sites decreases with decrease of the synthesis temperature. The highest number of Brønsted 
acid sites $(189 \mu \mathrm{mol} / \mathrm{g})$ exhibits ZSM-5 $\left(150{ }^{\circ} \mathrm{C}\right)$ while this amount is two times lower for ZSM$5\left(100^{\circ} \mathrm{C}\right)$. This result correlates well with the results of ${ }^{27} \mathrm{Al}$ MAS NMR and OH-FTIR analyses. It is important to note that decrease of the amount of Brønsted acid sites is not accompanied by increase of Lewis acidity. It supports the previous assumption that the sample crystallized at low temperature contains some extra framework $\mathrm{Al}$ (EFAl), but this aluminum is namely present in low acidic form, most probably as dense amorphous aluminosilicate.

The strength of the acid sites was studied by pyridine desorption during increase of the temperature of the sample under continuous evacuation. Figure 9 shows that increase of the temperature leads to decrease of the intensity of the peaks of pyridine adsorbed over Brønsted and Lewis acid sites. Higher strength of the acid sites should result in the higher temperature necessary for desorption of pyridine. Adsorption of pyridine over Brønsted acid sites is stronger than over Lewis acid sites, however, at high temperatures there is a stable form of pyridine over Lewis acid sites which cannot be easily desorbed. Figure 9 indicates on the comparable strength of the Brønsted acid sites in the industrial sample and the samples crystallized at 150 and $170{ }^{\circ} \mathrm{C}$. Samples crystallized at low temperatures $\left(100^{\circ} \mathrm{C}\right.$ and $\left.120^{\circ} \mathrm{C}\right)$ demonstrate rather lower strength of the acid sites. Similar trend was observed in the case of Lewis acid sites, i.e., the acid strength decreased slightly with the decrease of the crystallization temperature. This result correlates well with observed lower

Table 2. Si/Al ratio and concentration of Brønsted (B) and Lewis (L) acid sites determined by IR analysis of adsorbed pyridine (Py).

\begin{tabular}{|c|c|c|c|}
\hline Sample & $\mathrm{Si} / \mathrm{Al}^{\mathrm{ICP}}$ & $\begin{array}{l}n(\mathrm{~B}-\mathrm{Py}) \\
\mu \mathrm{mol} \mathrm{g} \mathrm{g}^{-1}\end{array}$ & $\begin{array}{c}n(\mathrm{~L}-\mathrm{Py}) \\
\mu \mathrm{mol} \mathrm{g}{ }^{-1}\end{array}$ \\
\hline ZSM-5(ind) & 25 & 582 & 128 \\
\hline ZSM-5 $\left(170^{\circ} \mathrm{C}\right)$ & 27 & 138 & 126 \\
\hline $\mathrm{ZSM}-5\left(150^{\circ} \mathrm{C}\right)$ & 31 & 189 & 155 \\
\hline $\mathrm{ZSM}-5\left(120^{\circ} \mathrm{C}\right)$ & 25 & 89 & 114 \\
\hline $\mathrm{ZSM}-5\left(100^{\circ} \mathrm{C}\right)$ & 35 & 79 & 88 \\
\hline
\end{tabular}

crystallinity of the samples synthesized at lower temperature. Comparable effect was reported during the dealumination ${ }^{[57]}$ or recrystallization of zeolites ${ }^{[58]}$. It is in line with the theory that stronger sites are located in the areas with high crystallinity and long range symmetry, while weak sites exist in non well-crystallized areas. ${ }^{[59]}$ 

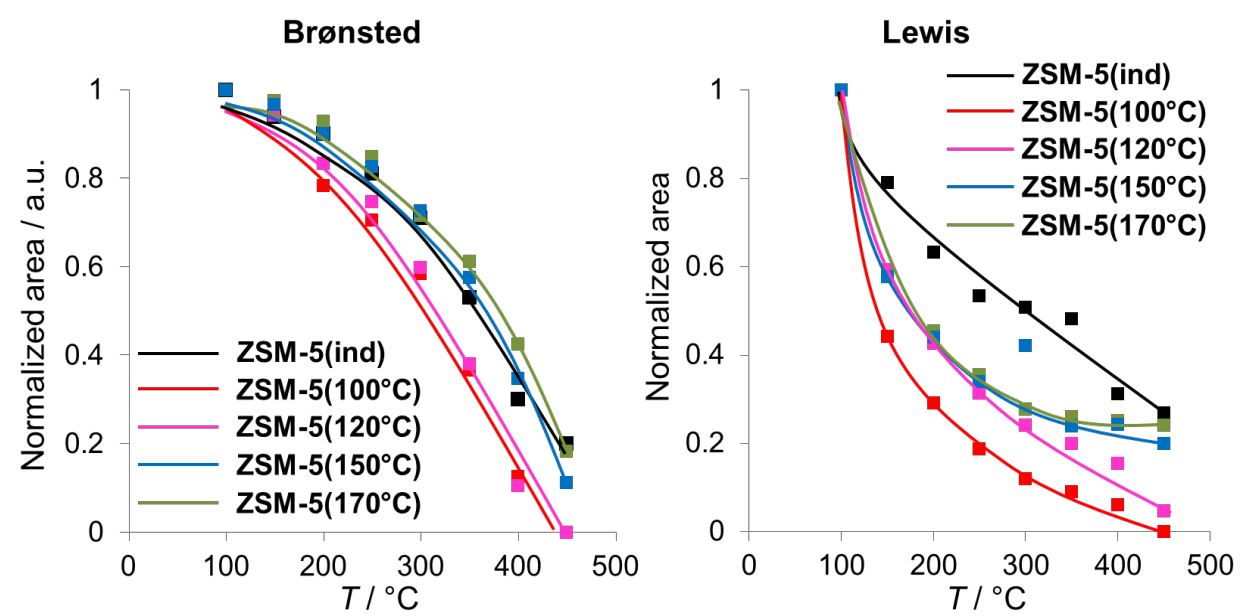

Figure 9. Normalized area for adsorbed Py over Brønsted $\left(1545 \mathrm{~cm}^{-1}\right)$ and Lewis $\left(1454 \mathrm{~cm}^{-1}\right)$ acid sites during desorption with increase of the temperature over industrial and nanosized zeolites prepared at different crystallization temperatures.

\section{Catalytic performance and catalysts deactivation}

Figure 10 shows the methanol conversion over homemade and industrial catalysts as a function of TOS at $450{ }^{\circ} \mathrm{C}$. Initially, all the catalysts show near $100 \%$ conversion. The rate of deactivation differs substantially than the industrial sample, which lost activity after $30 \mathrm{~h}$ on stream. The conversion profiles of other catalysts widely varied with the crystallization temperature: ZSM$5\left(120^{\circ} \mathrm{C}\right)$ and $\mathrm{ZSM}-5\left(170^{\circ} \mathrm{C}\right)$ deactivated after $60 \mathrm{~h}$ of test, while ZSM-5 $\left(150^{\circ} \mathrm{C}\right)$ demonstrated higher stability and was active up to $80 \mathrm{~h}$. The best performance was recorded for $\mathrm{ZSM}-5\left(100^{\circ} \mathrm{C}\right)$ sample which deactivated after $100 \mathrm{~h}$ of the reaction.

The major products of the MTO reaction over all samples were light alkanes and olefins such as ethylene, propylene, and butenes (Table 3, Figure 11) with the selectivity to these products about 60 $\%$ at $20 \mathrm{~h}$ TOS (Table 3). Heavier hydrocarbons and aromatics $\left(\mathrm{C}_{5}^{+}\right)$contribute to the rest of the products. ZSM-5(ind) catalyst demonstrated significant selectivity to light alkanes at the beginning of the test. Figure 11 shows that the yield of light alkanes is decreasing and the production of light olefins is increasing in time over ZSM-5(ind). Thus, the yield to propane is decreasing from 22 to 2 $\%$ while the yield to propylene increases from 4 to $29 \%$ during the first $35 \mathrm{~h}$ of the test. It is interesting to note that although the ratio of olefins to alkanes changes significantly during the reaction the ratio of propylene to ethylene is not much affected. The ratio $\mathrm{C}_{3} \mathrm{H}_{6} / \mathrm{C}_{2} \mathrm{H}_{4}$ increases from 


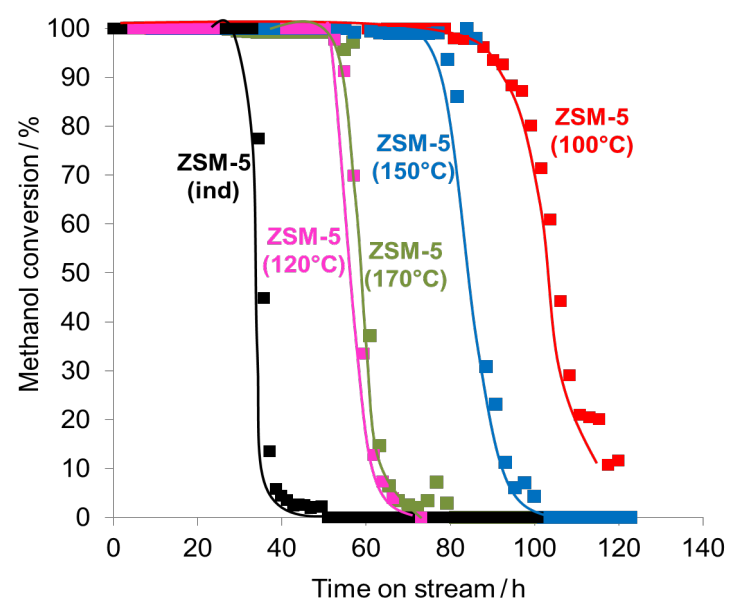

Figure 10. Methanol conversion versus time on stream over industrial and nanosized zeolites prepared at different crystallization temperatures $\left(T=450{ }^{\circ} \mathrm{C}, p=0.1 \mathrm{MPa}, \mathrm{WHSV}=1 \mathrm{~h}^{-1}\right)$.

1 to 1.3 which is close to the ratio usually observed over ZSM-5 catalysts (Table 3). Light alkanes and aromatics are referred to as hydrogen transfer products in the MTO reaction. The hydrogen transfer activity is usually measured in methanol chemistry by Hydrogen Transfer Index (HTI), which is defined as the ratio of $\mathrm{C}_{4}$ alkanes to the total $\mathrm{C}_{4}$ concentration $\left(\mathrm{C}_{4}\right.$ alkanes and olefins). High HTI indicates a high activity in transformation of olefins to aromatics and alkanes. ZSM5(ind) shows HTI 0.65 at $20 \mathrm{~h}$ TOS (Table 3).

MTO reaction over nanosized zeolites shows significantly different behavior in comparison with the industrial sample. Nanosized samples show much higher selectivity to light olefins with lower contribution of heavier hydrocarbons $\left(\mathrm{C}_{5}{ }^{+}\right)$, aromatics and $\mathrm{C}_{1}-\mathrm{C}_{4}$ alkanes (Table 3). Thus, ZSM$5\left(170^{\circ} \mathrm{C}\right)$ has almost two times lower selectivity $(12.4 \%)$ to light alkanes and almost two times higher selectivity to light olefins $\left(54.6 \%\right.$ for ZSM- $5\left(170^{\circ} \mathrm{C}\right)$ in respect with ZSM-5(ind)). In

Table 3. MTO reaction over studied ZSM- 5 catalysts $\left(\mathrm{T}=450^{\circ} \mathrm{C}, \mathrm{p}=0.1 \mathrm{MPa}, \mathrm{WHSV}=1 \mathrm{~h}^{-1}\right.$, TOS $=$ $20 \mathrm{~h})$.

\begin{tabular}{|c|c|c|c|c|c|c|c|c|}
\hline \multirow{2}{*}{ Sample } & \multirow{2}{*}{$\begin{array}{c}\text { Conv. } \\
(\%)\end{array}$} & \multicolumn{5}{|c|}{ Selectivity (C- mol \%) } & \multirow{2}{*}{$\mathrm{C}_{3} \mathrm{H}_{6} / \mathrm{C}_{2} \mathrm{H}_{4}$} & \multirow{2}{*}{$\mathrm{HTI}-\mathrm{C}_{4}$} \\
\hline & & $\mathrm{C}_{1}-\mathrm{C}_{4}$ & $\mathrm{C}_{2} \mathrm{H}_{4}$ & $\mathrm{C}_{3} \mathrm{H}_{6}$ & $\mathrm{C}_{4} \mathrm{H}_{8}$ & $\mathrm{C}_{5}^{+}$ & & \\
\hline ZSM-5(ind) & 100 & 25.0 & 14.6 & 14.9 & 3.1 & 42.4 & 1.0 & 0.65 \\
\hline $\mathrm{ZSM}-5\left(170^{\circ} \mathrm{C}\right)$ & 100 & 12.4 & 22.3 & 26.6 & 5.7 & 33.0 & 1.2 & 0.43 \\
\hline $\mathrm{ZSM}-5\left(150^{\circ} \mathrm{C}\right)$ & 99.5 & 10.1 & 17.5 & 24.2 & 5.3 & 42.9 & 1.4 & 0.42 \\
\hline $\mathrm{ZSM}-5\left(120^{\circ} \mathrm{C}\right)$ & 99.7 & 8.0 & 11.3 & 42.0 & 10.4 & 28.3 & 3.7 & 0.33 \\
\hline $\mathrm{ZSM}-5\left(100^{\circ} \mathrm{C}\right)$ & 99.9 & 7.7 & 8.4 & 53.3 & 14.3 & 16.3 & 6.3 & 0.30 \\
\hline
\end{tabular}



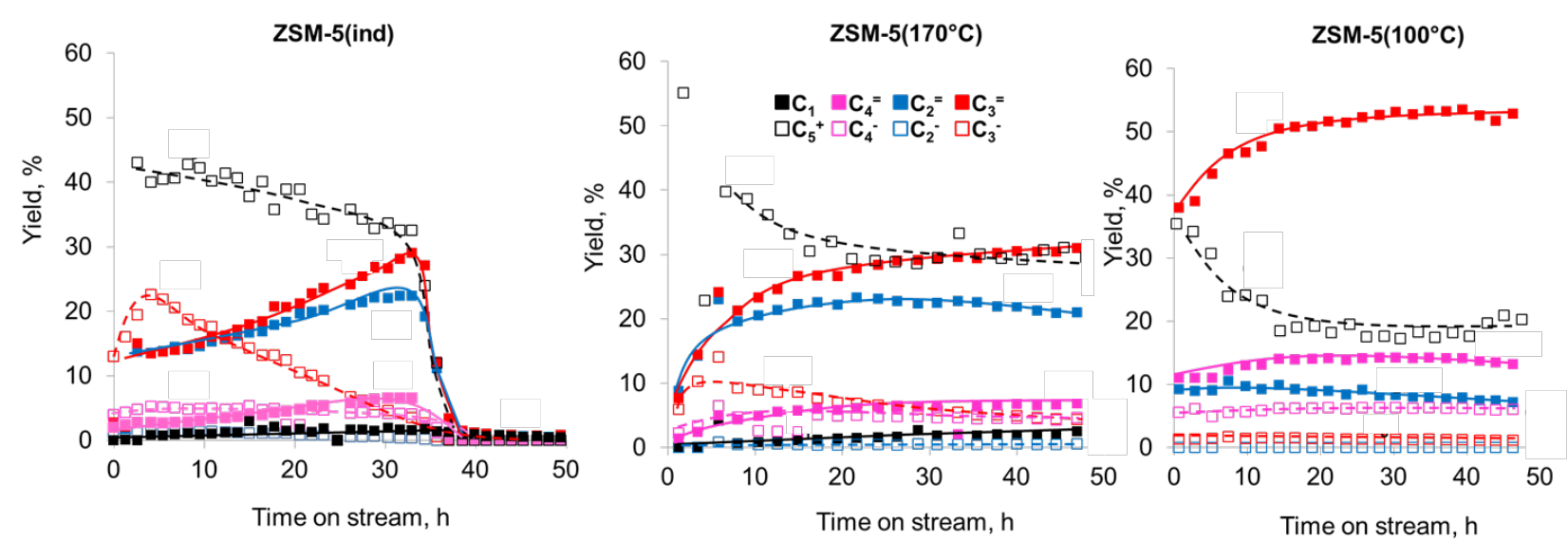

Figure 11. Products yield during MTO reaction over ZSM-5(ind), ZSM-5 $\left(170^{\circ} \mathrm{C}\right)$ and ZSM$5\left(100^{\circ} \mathrm{C}\right)$ versus time on stream $\left(\mathrm{T}=450^{\circ} \mathrm{C}, \mathrm{p}=0.1 \mathrm{MPa}, \mathrm{WHSV}=1 \mathrm{~h}^{-1}\right)$.

contrast with the industrial material the sample synthesized at ZSM-5 $\left(170^{\circ} \mathrm{C}\right)$ does not show abrupt changes in the distribution of the hydrocarbons with time on stream and the selectivity to propylene is moderately increasing in time. On the other hand, the selectivity to ethylene is slightly decreasing. Nanosized sample demonstrates significantly lower hydrogen transfer activity in comparison with ZSM-5(ind). Indeed, HTI decreases from 0.65 for ZSM-5(ind) to 0.43 for ZSM$5\left(170^{\circ} \mathrm{C}\right)$. It explains lower selectivity to alkanes and aromatics and higher selectivity to light olefins. Note that despite of significant changes in the products distribution the ratio of propylene to ethylene for nanosized sample ZSM-5 $\left(170^{\circ} \mathrm{C}\right)$ remains similar to the industrial sample (Table 3$)$. Further, for the sample prepared at $150{ }^{\circ} \mathrm{C}$ the ratio of propylene to ethylene is similar to ZSM$5\left(170^{\circ} \mathrm{C}\right)$, 1.4. Interestingly, this sample showed similar HTI but lower selectivity to olefins in comparison with $\mathrm{ZSM}-5\left(170^{\circ} \mathrm{C}\right)-47$ and $54.6 \%$. Significant change in P/E ratio is observed for the ZSM-5 $\left(120^{\circ} \mathrm{C}\right)$ and $\mathrm{ZSM}-5\left(100^{\circ} \mathrm{C}\right), 3.7$ and 6.3 respectively. Moreover, the decrease of the temperature of crystallization results in further decrease of the hydrogen transfer activity - from HTI of $0.42\left(150{ }^{\circ} \mathrm{C}\right.$ sample) to $0.3\left(100{ }^{\circ} \mathrm{C}\right.$ sample) and selectivity to light alkanes and $\mathrm{C}_{5}{ }^{+}$ hydrocarbons. These changes are coupled with increase of the selectivity to olefins - at $20 \mathrm{~h}$ TOS the selectivity to propylene is $42.0 \%$ over ZSM-5 $\left(120^{\circ} \mathrm{C}\right)$ and $53.3 \%$ over ZSM-5 $\left(100^{\circ} \mathrm{C}\right)$ catalyst.

In Figure 12 is displayed the correlation of the ratio of propylene to ethylene with the reciprocal HTI. It shows that lower HTI results in higher selectivity to propylene. The effect of HTI on the selectivity is not linear and increases significantly at low values of hydrogen transfer activity.

TG analysis of the spent nanosized ZSM-5 samples (after $120 \mathrm{~h}$ TOS) was performed. The TG curves exhibit first weight loss in the range from room temperature till $140{ }^{\circ} \mathrm{C}$ which is attributed to desorption of volatile species (Figure 13). The weight content of these species is from $1.4 \mathrm{wt} \%$ for the sample $\mathrm{ZSM}-5\left(170^{\circ} \mathrm{C}\right)$ to $2.4 \mathrm{wt} \%$ for $\mathrm{ZSM}-5\left(120^{\circ} \mathrm{C}\right)$. The industrial sample does not show any 


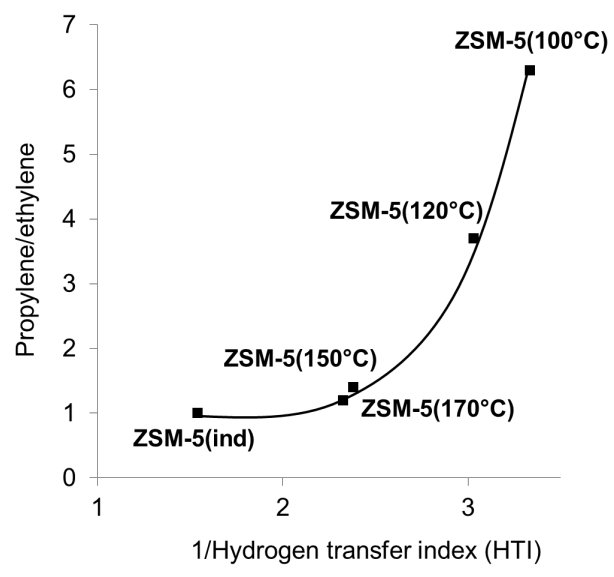

Figure 12. Propylene to ethylene ratio versus reciprocal HTI over industrial and nanosized zeolites prepared at different crystallization temperatures $\left(\mathrm{T}=450^{\circ} \mathrm{C}, \mathrm{p}=0.1 \mathrm{MPa}, \mathrm{WHSV}=1 \mathrm{~h}^{-1}, \mathrm{TOS}=\right.$ $20 \mathrm{~h})$.

significant changes in this temperature range revealing that there are almost no physisorbed species in this sample. The second weight loss, in the range $430-650{ }^{\circ} \mathrm{C}$, is attributed to highly condensed polyaromatic residues, often denoted as high-temperature coke. The sample $\mathrm{ZSM}-5\left(100^{\circ} \mathrm{C}\right)$ contains markedly lower amount of the coke than other studied samples $(6.34 \%)$. The industrial sample and the sample prepared at $120^{\circ} \mathrm{C}$ comprise similar quantity of carbonaceous deposits, 12.64 and $12.26 \%$ respectively. In the samples synthesized at high temperature there is almost three times higher amount of coke than in $100{ }^{\circ} \mathrm{C}$ sample $-23.39 \%$ in ZSM-5 $\left(150^{\circ} \mathrm{C}\right)$ and $21.71 \%$ in ZSM-5 $\left(170^{\circ} \mathrm{C}\right)$. The position of minimum of dTG curve (Table 3, Figure 13) of the sample ZSM$5\left(100^{\circ} \mathrm{C}\right)$ and ZSM-5(ind) is at approximately identical temperature -572 and $575{ }^{\circ} \mathrm{C}$, respectively. On the other hand, the minimum in other samples is found at 590 and $593{ }^{\circ} \mathrm{C}$. Furthermore, the range where the change takes place is notably broader for the samples prepared at higher temperature, 150 and $170{ }^{\circ} \mathrm{C}$. The obtained results clearly indicate difference in the nature, stability and location of the coke species deposited on the studied catalysts (Table 4). 

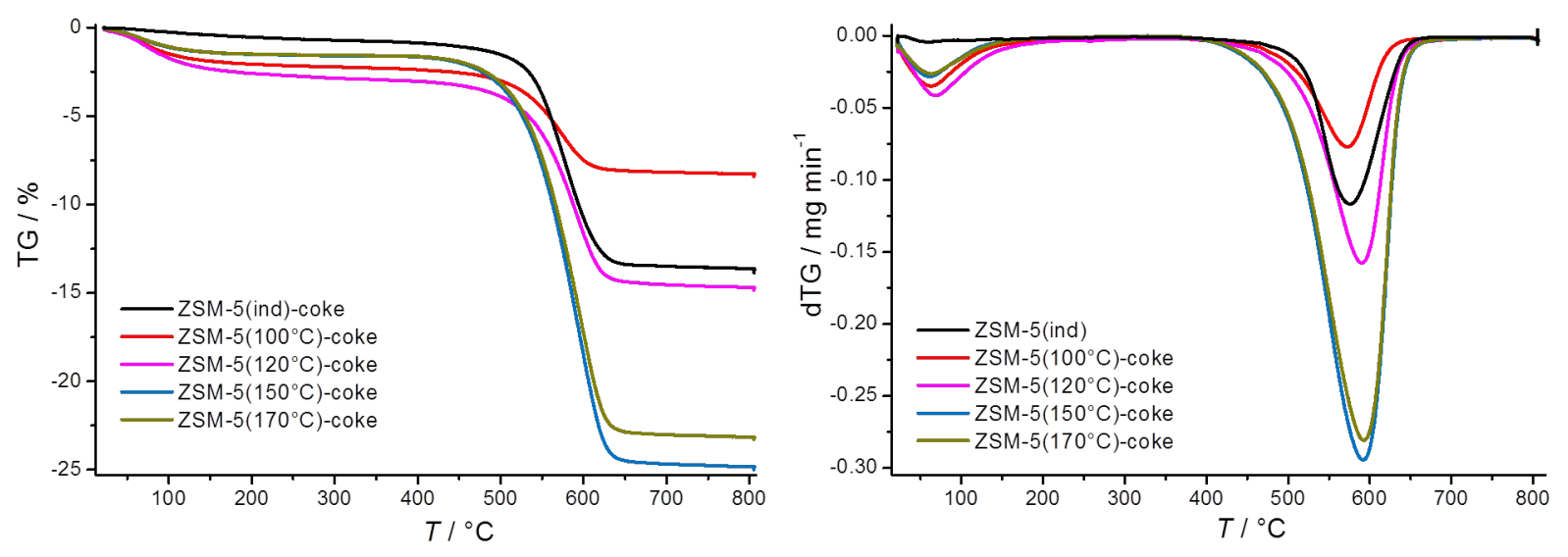

Figure 13. TGA (left-hand side) and dTG (right-hand side) curves of the studied nanosized and industrial ZSM-5 catalysts after being used in the MTO reaction.

Table 4. The TG and nitrogen adsorption analysis of the spent nanosized and industrial ZSM-5 catalysts in the MTO reaction. Weight loss and the dTG minimum are given for the range from 430 to $650{ }^{\circ} \mathrm{C}$.

\begin{tabular}{ccccccc}
\hline Sample & $\begin{array}{c}\text { weight loss } \\
\%\end{array}$ & $\begin{array}{c}T_{\min } \\
{ }^{\circ} \mathrm{C}\end{array}$ & $\begin{array}{c}S_{\text {BET }} \\
\mathrm{m}^{2} \mathrm{~g}^{-1}\end{array}$ & $\begin{array}{c}V_{\text {mic }} \\
\mathrm{cm}^{3} \mathrm{~g}^{-1}\end{array}$ & $\begin{array}{c}S_{\text {ext }} \\
\mathrm{m}^{2} \mathrm{~g}^{-1}\end{array}$ & $\begin{array}{c}V_{\text {total }} \\
\mathrm{cm}^{3} \mathrm{~g}^{-1}\end{array}$ \\
\hline ZSM-5(ind) & 12.64 & 575 & 41 & 0.02 & 2 & 0.200 \\
ZSM-5 $\left(170^{\circ} \mathrm{C}\right)$ & 21.71 & 593 & 188 & 0.07 & 25 & 0.254 \\
ZSM-5 $\left(150^{\circ} \mathrm{C}\right)$ & 23.39 & 593 & 181 & 0.07 & 27 & 0.264 \\
ZSM-5 $\left(120^{\circ} \mathrm{C}\right)$ & 12.26 & 590 & 273 & 0.11 & 57 & 0.411 \\
ZSM-5 $\left(100^{\circ} \mathrm{C}\right)$ & 6.34 & 572 & 359 & 0.12 & 77 & 0.488 \\
\hline
\end{tabular}

Nitrogen adsorption measurements of spent catalysts show different degree of pore blockage. (Table 4). The micropore volume of the industrial samples is fully blocked by coke species, while the decrease of micropore volume varies between 60 and $15 \%$ for the nanosized ZSM-5 samples. More precisely, $60 \%$ decrease of the micropore volume is observed for ZSM-5 $\left(150^{\circ} \mathrm{C}\right)$ and ZSM$5\left(170^{\circ} \mathrm{C}\right)$ samples. The decrease for $\mathrm{ZSM}-5\left(120^{\circ} \mathrm{C}\right)$ and $\mathrm{ZSM}-5\left(100^{\circ} \mathrm{C}\right)$ is 25 and $15 \%$, respectively. These data match well with the TGA results which showed higher coke content in the samples synthesized at 150 and $170{ }^{\circ} \mathrm{C}$. ZSM-5 $\left(120^{\circ} \mathrm{C}\right)$ and ZSM-5(ind) exhibit similar amount of coke. Nevertheless, the micropore volume of nanosized sample remains partially accessible for the $\mathrm{N}_{2}$ molecule, while the micropore volume of micron-sized crystals is fully blocked (Table 4). The most plausible explanation of this phenomenon is the shorter diffusion path in the nanosized sample, which allows substantial part of the coke to migrate and deposit on the external surface of the crystallites. This statement is based on a previous study which showed that the coke species are 
deposited on the external surface of nanosized ZSM-5 crystals, in contrast to the abundant coke formation in the pores of the micron-sized counterpart. ${ }^{[60]}$ Different nature of the coke formed in the nano- and micron-sized crystals could also contribute to the observed differences in the accessibility at similar coke content.

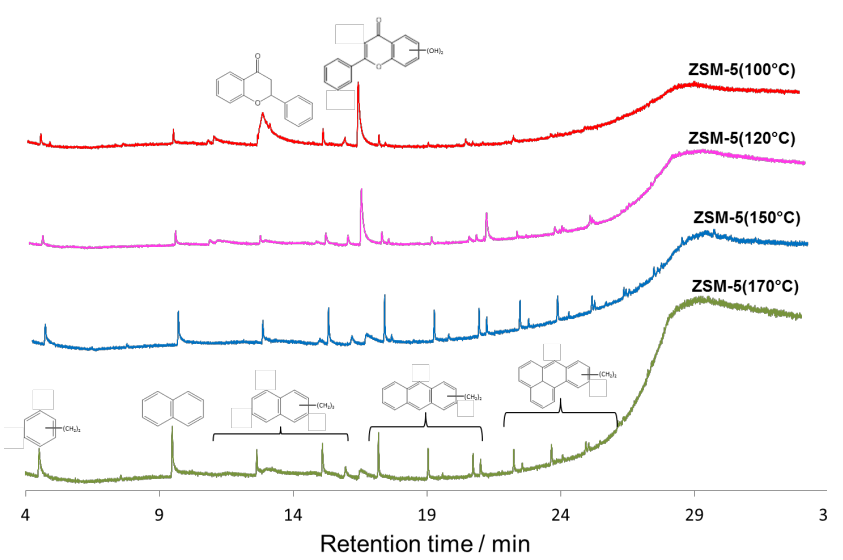

Figure 14. GC-MS analyses of organics extracted by dichlormethane from the spent nanosized ZSM-5 catalysts.

In order to ascertain the nature of the coke species in the spent ZSM-5 catalysts, the samples were treated with toluene. Any organic compound was found in the extracted solvent showing the absence of dissolvable coke in the spent catalysts. Further, the zeolite has been dissolved in HF and the organic part extracted with dichlormethane. The coke molecules were subjected to GC-MS analysis (Figure 14). The GC-MS analysis of the coke formed in the ZSM-5(ind) did not provide peaks that could be used to reveal the nature of the coke. Obviously, mostly "heavy" coke insoluble in toluene and $\mathrm{CH}_{2} \mathrm{Cl}_{2}$ was formed in the industrial sample. The chromatograms of the samples ZSM-5 $\left(150^{\circ} \mathrm{C}\right)$ and ZSM-5 $\left(170^{\circ} \mathrm{C}\right)$ are almost identical and show presence of alkylated polycyclic aromatic compounds like naphthalene and anthracene. It is important to note that there is larger variety of coke species in the samples ZSM-5 $\left(150^{\circ} \mathrm{C}\right)$ and $\mathrm{ZSM}-5\left(170^{\circ} \mathrm{C}\right)$ which contain the highest amount of coke. Only traces of polycyclic aromatic compounds were found in the ZSM- $5\left(100^{\circ} \mathrm{C}\right)$ and ZSM-5 $\left(120^{\circ} \mathrm{C}\right)$. New partially hydrogenated oxygen containing species on the basis of oxane have been observed in the chromatograms. The coke analysis of ZSM-5 $\left(100^{\circ} \mathrm{C}\right)$ differs substantially in the elemental composition and in the region of heavier species where a negligible amount of coke was found. The $120{ }^{\circ} \mathrm{C}$ sample is a merger between ZSM-5 $\left(100{ }^{\circ} \mathrm{C}\right)$ and ZSM-5 $\left(150^{\circ} \mathrm{C}\right) / \mathrm{ZSM}$ $5\left(170^{\circ} \mathrm{C}\right)$. There are peaks corresponding to heavier species present in its chromatogram together with peaks found in ZSM-5 $\left(100{ }^{\circ} \mathrm{C}\right)$, but of significantly lower intensity. Likewise, as the coke quantity decreases it becomes less diverse (complex) leading to the conclusion that the factors causing the deactivation of the catalysts differ in the studied set of the samples.

The analysis of the spent ZSM-5 catalysts shows that the insoluble coke in the industrial sample 
comprises highly polyaromatic species of graphitic character. Although the amount of coke is lower than in the case of ZSM-5 $\left(150^{\circ} \mathrm{C}\right)$ and $\mathrm{ZSM}-5\left(170^{\circ} \mathrm{C}\right)$ samples, the micropore volume is completely blocked. It can be assumed that the coke is namely situated in the intersections of straight and zigzag channels, thus blocking the access to active sites. On the other hand, the nanosized sample retain certain degree of microporosity, even in the case of $\mathrm{ZSM}-5\left(150^{\circ} \mathrm{C}\right)$ and $\mathrm{ZSM}-5\left(170^{\circ} \mathrm{C}\right)$ samples, which exhibit almost two times higher coke content. This result unambiguously proves that a substantial part of the coke is deposited on the external surface of zeolite nanoparticles and a certain part of micropore volume remains accessible.

\section{Discussion}

The catalytic performance of the industrial ZSM-5 sample in the MTO reaction is similar to the results reported in the literature. ${ }^{[13,14]}$ We have employed this sample as a reference in order to evaluate the catalytic performance to the nanosized ZSM-5 synthesized under different temperature and thus to apprehend better the impact of physiochemical properties on zeolite activity. Namely, the differences with respect to the size and acid site density provide broader range of the studied factors and subsequently the overall process can be elucidated to a greater degree as it is going to be demonstrated in the forthcoming discussion.

The dual cycle mechanism is generally accepted for methanol to olefins formation over ZSM-5. Basically, ethylene and equal quantity of propylene are generated by the aromatic based hydrocarbon pool mechanism (aromatic cycle), while higher olefins are generated by olefins methylation and subsequent cracking (alkene cycle). ${ }^{[18]}$ Hydrogen transfer reaction is a secondary reaction in MTO process and represents a connection between the two cycles. It involves the transformation of higher alkenes formed in the alkene cycle to alkanes and aromatics. Brønsted acid sites are required for the methanol dehydration ${ }^{[61]}$ and to promote the formation of the hydrocarbon pool species. In addition, polycyclic aromatic species formed on Brønsted acid sites enhance the probability of catalysts deactivation. On the contrary, the alkene pathway is promoted by low catalyst acidity. It is important to note that the catalyst activity and deactivation can be affected by different factors. For example, the catalytic activity depends on the diffusion rate of the methanol or DME while deactivation is a function of the diffusion of hydrocarbon species, expectedly polymethylbenzenes in the case of ZSM-5 catalyst. As already mentioned, the crystal size and textural properties have also been shown to play an important role in the MTO catalyst performance. $^{[18]}$

The distinct product selectivities, propylene to ethylene ratio and HTI clearly indicate the differences in the mechanism of the MTO reaction over the studied set of samples. There are two 
extreme examples - the sample ZSM-5 $\left(100^{\circ} \mathrm{C}\right)$ and $\mathrm{ZSM}-5$ (ind). In the industrial sample the propylene/ethylene ratio is the lowest and HTI the highest at $20 \mathrm{~h}$ TOS (Figure 12, Table 3). Large crystals and high acid site density in the ZSM-5(ind) favor ethylene formation. ZSM-5 $\left(170^{\circ} \mathrm{C}\right)$ exhibits similar propylene to ethylene ratio (1.2), but higher selectivity towards both ethylene and propylene. Moreover, HTI is lower for the ZSM-5 $\left(170^{\circ} \mathrm{C}\right)$ sample. Although these two catalysts demonstrate similar propylene/ethylene ratio (Table 3), the different selectivities should arise from lower amount of acid sites and the smaller crystal size of the later catalyst. The situation is opposite for the ZSM-5 $\left(100^{\circ} \mathrm{C}\right)$ and ZSM-5 $\left(120^{\circ} \mathrm{C}\right)$ samples which exhibit slightly smaller size in respect to ZSM-5 $\left(170^{\circ} \mathrm{C}\right)$ yet substantially lower acidity. The propylene is the major product of the reaction for these two samples. Different carbon species formed on different zeolites provide another strong indication of different predominant reaction pathways over these samples. The nature of the coke formed on different samples also suggests different reaction mechanism. Indeed, the samples crystallized at lower temperatures $\left(100^{\circ} \mathrm{C}\right.$ and $\left.120^{\circ} \mathrm{C}\right)$ contain totally different types of coke species in comparison with zeolites obtained at higher temperatures $\left(150^{\circ} \mathrm{C}\right.$ and $\left.170^{\circ} \mathrm{C}\right)$. Predominant nonaromatic coke species formed on ZSM-5 $\left(100^{\circ} \mathrm{C}\right)$ and $\mathrm{ZSM}-5\left(120^{\circ} \mathrm{C}\right)$ point out that the alkene cycle controls the reaction leading to selective propylene synthesis. The main difference between the samples synthesized at low and high temperatures is the acid sites strength and the external surface area (Table 1). The observed variation in catalytic performance and the selectivity in particular is a consequence of the impact of different factors. Figure S1 shows the dependence of C3 yield versus number of Brønsted acid sites defined by Py adsorption. For example, catalysts crystallized at 100 ${ }^{\circ} \mathrm{C}, 120^{\circ} \mathrm{C}$ and $150{ }^{\circ} \mathrm{C}$ have very similar amount of acid sites according to solid state NMR and FTIR adsorption of Py, however, the yield of propylene is much lower in the case of ZSM$5\left(100^{\circ} \mathrm{C}\right)$. Thus, the acid sites density seems to have a negligible effect on the propylene selectivity. At the same time, there is a clear dependence of propylene yield on the relative strength of acid sites defined by pyridine desorption at $200^{\circ} \mathrm{C}$ (Figure 9). The yield of propylene (Figure S2, SI) clearly increases with decrease of the strength of acid sites which indicates the key role of this factor in the reaction. We attribute lower acidity of $100{ }^{\circ} \mathrm{C}$ and $120^{\circ} \mathrm{C}$ samples to more defected structure of zeolites synthesized under milder conditions. These samples exhibit also higher external surface and larger presence of surface silanols (Figure 7).

Another possible explanation of significant change in the catalytic behavior of the catalysts synthesized at low temperature could be the presence of extra-framework Al and defected silanols groups. These sites might possess weak acidity and participate in activation of methanol to olefins. In order to check this assumption we have synthesized aluminum-rich sample using TPAOH as a structure directing agent. In order to maximise the amount of extra-framework Al species and surface hydroxyls we have employed a gel with $\mathrm{Si} / \mathrm{Al}$ ratio of 5, which is much lower that a TPA 
templated ZSM-5 can accommodate in the framework. The resultant material is X-ray amorphous (Figure S3, SI) containing micropores (Figure S4, SI) and tetrahedral (framework) and octahedral (extra-framework) aluminium according to ${ }^{27} \mathrm{Al}$ MAS NMR (Figure S5, SI) without ZSM-5. Adsorption of Py revealed the presence of significant amount of Lewis acid sites formed by extraframework aluminium and much lower amount of Brønsted acid sites formed by tetrahedral aluminium (Table S1, SI). Further, in this material the isolated silanols at external and internal surface are by far the most dominant type of $\mathrm{OH}$ groups (Figure S6, SI). Catalytic test of this material conducted at the same reaction conditions as in the case of nanosized and industrial ZSM-5 samples did not show any activity in methanol transformation to olefins. We attribute this result to the fact that the Brønsted acid sites in amorphous material have too low strength as shown by desorption of Py at $300{ }^{\circ} \mathrm{C}$ (Table S1, SI). These data show that neither extra-framework aluminium nor silanol groups cannot be responsible for methanol transformation to propylene over studied set of nanosized ZSM-5 samples. The results show also that the catalyst for this reaction cannot be totally amorphous. Herein, shorter diffusion path and larger surface for deposition of aromatic species in these samples propagate propylene formation as previously reported in literature. ${ }^{[62]}$ The lifetime of the industrial sample is three times shorter than $\mathrm{ZSM}-5\left(100^{\circ} \mathrm{C}\right)$ and two times shorter than $\mathrm{ZSM}-5\left(170^{\circ} \mathrm{C}\right)$ revealing the negative effect of higher acid site density and larger crystal size on the MTO reaction. This finding is in line with the studies where at high reaction temperature and acid site density large graphite-like coke compounds are formed in large ZSM-5 crystals inducing pore blocking. ${ }^{[63]}$ In summary, the coke rate formation is enhanced with the increasing acidity of the material, while the large crystal size limit the coke migration to the external surface of the crystals and thus the pores are rapidly blocked. Here might be the reason for the observed increase of the propylene and ethylene yield during the first $35 \mathrm{~h}$ of the test (Figure 11). It was shown previously that the quantity of the aromatics increases with the time on stream. ${ }^{[63]}$ Aromatic species are not only coke precursors, they are indispensable for the aromatic cycle that may result in: 1) increased amount of ethylene and propylene generated by aromatic cycle; and 2) continuous poisoning of the Brønsted acid sites. Consequently, the selectivity towards ethylene and propylene should be rising as long as the diffusion through the crystal is possible. The longest catalyst lifetime of the ZSM-5 $\left(100^{\circ} \mathrm{C}\right)$ sample can be explained in terms of lower acid site density, somewhat lower acid strength, shorter diffusion path and larger external surface area. The moderate acidity of ZSM-5 $\left(100^{\circ} \mathrm{C}\right)$ is particularly appropriate for the MTO reaction, while the lower acid site density together with short diffusion path hinder the pore blocking. Thus the catalyst lifetime is extended even upon partial blocking of the active sites. ${ }^{[64]}$

ZSM-5 $\left(120^{\circ} \mathrm{C}\right), \mathrm{ZSM}-5\left(150^{\circ} \mathrm{C}\right)$ and $\mathrm{ZSM}-5\left(170^{\circ} \mathrm{C}\right)$ exhibit catalytic behavior in between the sample prepared at $100{ }^{\circ} \mathrm{C}$ and the industrial sample. Decrease of the propylene/ethylene ratio and 
selectivity towards propylene with rising the ZSM-5 synthesis temperature can be attributed to variations in the contributions of MTO reaction pathways from primary alkene towards primary aromatic cycle due to the higher acidity, lower external surface area and slight, but still notable increase of the crystal size. TG and nitrogen adsorption data imply that more and more coke is generated as the crystallization temperature gets higher and crystals get larger. The only surprising feature is the unexpectedly short catalyst lifetime of the $120{ }^{\circ} \mathrm{C}$ sample, $60 \mathrm{~h}$. In term of physicochemical properties this sample is situated between $\mathrm{ZSM}-5\left(100^{\circ} \mathrm{C}\right)$ and the samples synthesized at higher $\left(150\right.$ and $\left.170^{\circ} \mathrm{C}\right)$ temperatures. There is not a particular feature of this sample that we could relate with shorter lifetime. On the other hand, ZSM-5 $\left(120^{\circ} \mathrm{C}\right)$ stays between ZSM$5\left(100^{\circ} \mathrm{C}\right)$ and high temperature samples in term of propylene selectivity.

Hydrogen transfer reaction rates depend on the amount of acid sites, strength and the structure of zeolite. ${ }^{[65,66]}$ It has been shown that on $\mathrm{Al}_{2} \mathrm{O}_{3}$ adjacent acid sites rapidly participate in hydrogen transfer. ${ }^{[67]}$ Hence, in the case of ZSM-5(ind) the presence of high amount of strong acid sites leads to intensive hydrogen transfer reaction with formation of alkanes and condensed aromatic structures resulting in coke deposition and total pore blocking. As expected, the HTI value is getting lower with the decreasing acid site density. However, the lower amount of acid sites and larger crystal sizes in $\mathrm{ZSM}-5\left(170^{\circ} \mathrm{C}\right)$ does not lead to significant changes in propylene/ethylene ratio. At the same time, the decrease of the acid sites density and strength of acid sites in the nanosized zeolites having slightly lower size of the crystals but different external surface area leads to further decrease of hydrogen transfer activity. Indeed, the plot of HTI versus number of Brønsted acid sites (Figure S7, SI) does not show clear correlation which points out the importance of acid site strength in hydrogen transfer. The obtained data suggest that the mechanism of the MTO reaction is a result of complex interplay between particle size, number and strength of active sites.

To sum up, the best catalytic performance has been attained over zeolite crystallized at the lowest temperature $\left(100^{\circ} \mathrm{C}\right)$. The catalyst demonstrated the highest stability and selectivity to propylene. The propylene and light olefins yield over $\mathrm{ZSM}-5\left(100^{\circ} \mathrm{C}\right)$ is compared with the available literature data (Table S2). As can be seen the catalyst obtained at very low temperature demonstrates the highest selectivity to propylene and yield of light olefins. The ratio of propylene to ethylene was 6.3 and the selectivity to propylene $53 \%$, which is among the highest selectivities reported in the literature.$^{[10-17, \text { SI 1-7] }}$ The most important characteristics of this catalyst are very small nanosized particles built of intergrown crystalline domains responsible for large external surface area and their lower acid sites strength and density. 


\section{Conclusions}

The impact of crystallization temperature on the physicochemical properties of ZSM-5 is investigated. The lowering of the crystallization temperature from $170{ }^{\circ} \mathrm{C}$ to $100{ }^{\circ} \mathrm{C}$ resulted in decreasing the size of crystalline domains, slight decreasing of the particle size from 140 to $100 \mathrm{~nm}$, rising of the external surface area, lower crystallinity and reduced acid site density and strength. The crystallization at lower temperatures $\left(100\right.$ and $\left.120{ }^{\circ} \mathrm{C}\right)$ led to reduced incorporation of aluminium in the zeolite framework and deposition of amorphous alumosilicate species within the ZSM-5 particles.

Nanosized zeolites exhibit much higher stability in comparison with the industrial micron-sized sample of similar bulk $\mathrm{Si} / \mathrm{Al}$ ratio. In addition, the overall selectivity to olefins and especially to propylene is getting higher as the zeolite preparation temperature is decreasing. The set of experimental data revealed that this effect is due to the shift from prevailing aromatic-based to olefin-based cycle in MTO reaction. Namely it has been shown that these two simultaneously occurring cycles can be adjusted by varying the acid site density, acid sites strength, the size of zeolite crystals and the external surface area. Consequently, the selectivity towards desired product can be obtained. Herein was realized the highest selectivity to propylene of $53 \%$ with propylene to ethylene ratio 6.3 over nanosized ZSM-5 catalyst crystallized at $100{ }^{\circ} \mathrm{C}$. Thus, the zeolite synthesis conditions and the crystallization temperature in particular could be used to tune the catalytic activity of zeolites.

\section{Experimental Section}

\section{Catalyst preparation}

The first step in the preparation of the nanosized ZSM-5 crystals was mixing of the appropriate amounts of sodium aluminate $\left(\mathrm{NaAlO}_{2}\right.$, Riedel de Haën, $\left.\mathrm{w}\left(\mathrm{Al}_{2} \mathrm{O}_{3}\right)=54 \%, \mathrm{w}\left(\mathrm{Na}_{2} \mathrm{O}\right)=41 \%\right)$, tetrapropylammonium hydroxide (TPAOH, Alfa Aesar, 20 wt. \% water solution) and distilled water. The mixture was agitated with magnetic stirrer until the system became clear. Thereafter, tetraethoxysilane (TEOS, Aldrich, $98 \%$ ) was added to the solution and hydrolyzed at $80{ }^{\circ} \mathrm{C}$ for 24 h. The final molar oxide composition of the reaction mixture was 1.23 $\mathrm{Na}_{2} \mathrm{O}: 9.74 \mathrm{TPAOH}: 1.0 \mathrm{Al}_{2} \mathrm{O}_{3}: 43.2 \mathrm{SiO}_{2}: 806 \mathrm{H}_{2} \mathrm{O}$. Aliquots of clear solution were divided in four autoclaves and heated at $100,120,150$ and $170{ }^{\circ} \mathrm{C}$. The synthesis at $100{ }^{\circ} \mathrm{C}$ was performed for 7 days. The duration of the syntheses at 120,150 and $170{ }^{\circ} \mathrm{C}$ was 5 days. The prepared samples are further referred as ZSM-5 $\left(100^{\circ} \mathrm{C}\right)$, ZSM-5 $\left(120^{\circ} \mathrm{C}\right), \mathrm{ZSM}-5\left(150^{\circ} \mathrm{C}\right)$ and ZSM-5 $\left(170^{\circ} \mathrm{C}\right)$. Recovered solid phases were washed with distilled water until the $\mathrm{pH}$ of the supernatant was 7 , dried at $80{ }^{\circ} \mathrm{C}$ and calcined at $550{ }^{\circ} \mathrm{C}$ for $5 \mathrm{~h}$ (heating rate $1.75^{\circ} \mathrm{C} / \mathrm{min}$ ). The calcined zeolites were three times ion 
exchanged with ammonium chloride solution $\left(c\left(\mathrm{NH}_{4} \mathrm{Cl}\right)=0.5 \mathrm{~mol} / \mathrm{dm}^{3}\right)$ at $80{ }^{\circ} \mathrm{C}$. For the sake of comparison, commercial zeolite ZSM-5 (NH4-form), denoted here as ZSM-5(ind), offered by SüdChemie (Clariant), lot number BEEZ 01081, was used in this study. The protonic forms were obtained by calcining the $\mathrm{NH}_{4}$-form of zeolites at $550{ }^{\circ} \mathrm{C}$ for $5 \mathrm{~h}$ with the heating ramp of 1.75 ${ }^{\circ} \mathrm{C} / \mathrm{min}$ in static air.

The amorphous material was synthesized using tetrapropylammonium hydroxide (TPAOH, Alfa Aesar, 1M), tetraethoxysilane (TEOS, Aldrich, 98\%), di-sec-butoxyaluminoxytriethoxysilane (DSBATES, ABCR GMBH) and doubly distilled water. The needed amount of TPAOH was mixed with the water in a polypropylene bottle. Then DSBATES was added and the mixture was stirred for $24 \mathrm{~h}$ followed by the addition of TEOS. The solution was stirred for additional $24 \mathrm{~h}$ and subsequently treated for 10 days at $100{ }^{\circ} \mathrm{C}$ in an oven. The molar composition of the reaction mixture was 25 DSBATES : 9 TPAOH : 125 TEOS : $500 \mathrm{H}_{2} \mathrm{O}$. The recovered solid phase has been washed three times with acetone and then with water until neutral $\mathrm{pH}$. The calcination was performed at $550^{\circ} \mathrm{C}$ for $5 \mathrm{~h}$.

\section{Physicochemical characterization}

The phase composition of the solid samples was analyzed by X-ray diffraction using PANalytical X'pert PRO MPD diffractometer with $\mathrm{CuK}_{\alpha}$ monochromatized radiation $(\lambda=1.5418 \AA, 45 \mathrm{kV}, 40$ $\mathrm{mA}$ ). The measurements were performed in the range of Bragg's angles $2 \theta=5-50^{\circ}$, step size of $0.0167^{\circ}$, time per step of $99.68 \mathrm{~s}$.

The electron micrographs of the prepared crystals were obtained by MIRA-LMH (Tescan) scanning electron microscope (SEM) equipped with field emission gun. The elemental analysis of the studied ZSM-5 materials was performed by inductively coupled plasma-atomic emission spectrometer (ICP-AES) OPTIMA 4300 DV (PerkinElmer).

Solid state NMR spectra were recorded on a Bruker Avance III (11.7 T) spectrometer using $4 \mathrm{~mm}$ OD zirconia rotors and a spinning frequency of $14 \mathrm{kHz}$. For ${ }^{27} \mathrm{Al}$ MAS NMR spectra pulse recycling delay was $1 \mathrm{~s}$ and a pulse length of 2.5 microseconds $(\pi / 12$, selective pulse) was applied. Single pulse excitation ( $30^{\circ}$ flip angle) of $3 \mu$ s was used for ${ }^{29} \mathrm{Si}$ MAS NMR experiment and $30 \mathrm{~s}$ of recycle delay. ${ }^{29} \mathrm{Si}\left\{{ }^{1} \mathrm{H}\right\}$ cross-polarization (CP) MAS experiments were performed with a contact time of $4 \mathrm{~ms}$ and a recycling time of $1 \mathrm{~s}$. The chemical shifts were referenced to a $0.1 \mathrm{M}$ aqueous solution of aluminium nitrate $\left(c\left(\mathrm{Al}\left(\mathrm{NO}_{3}\right)_{3}\right)=0.1 \mathrm{~mol} / \mathrm{dm}^{3}\right)$ and tetramethylsilane (TMS), respectively. The acquired spectra were normalized with respect to the weight of the corresponding sample. 
Nitrogen adsorption/desorption of the calcined samples and the samples used in catalytic tests was performed with a Micromeritics ASAP 2020 automated gas adsorption analyzer. The samples were outgassed at $300{ }^{\circ} \mathrm{C}$ under a vacuum overnight prior to the measurement. Specific surface areas were determined from the BET equation. The total pore volume was taken from nitrogen adsorbed volume at $p / p_{0}=0.99$. The $t$-plot method was used to distinguish the micropores from the mesopores and to calculate the external surface area. The mesopore size distributions of solids were estimated by Barret-Joyner-Halenda (BJH) method.

FTIR measurements were carried out on a Nicolet Magna 550-FTIR spectrometer at $4 \mathrm{~cm}^{-1}$ optical resolution. The pressing of the samples into self-supported discs (diameter $2 \mathrm{~cm}, 13 \mathrm{mg}$ ) preceded the measurements. Before acquiring the spectra at room temperature, each sample was pretreated in the IR cell connected to the vacuum line at $20{ }^{\circ} \mathrm{C}\left(0.33{ }^{\circ} \mathrm{C} / \mathrm{min}\right)$ for $1.5 \mathrm{~h}$ and at $500{ }^{\circ} \mathrm{C}(1.27$ ${ }^{\circ} \mathrm{C} / \mathrm{min}$ ) for $2 \mathrm{~h}$ under pressure $10^{-6}$ Torr. The obtained spectra were normalized to the weight of the self-supported disc.

The adsorption of pyridine was performed at temperature of $150{ }^{\circ} \mathrm{C}$. After establishing a pressure of 1 Torr at equilibrium, the cell was evacuated at room temperature. In order to study the strength of the interactions between the zeolite and the probe molecules, the samples were heated to $50-400{ }^{\circ} \mathrm{C}$ (step $50{ }^{\circ} \mathrm{C}$ ) and the spectra were taken at each temperature. Then, the amount of Brønsted and Lewis acid sites at each desorption temperature was calculated from the integrated area of the bands (after background subtraction) of adsorbed pyridine at $1545 \mathrm{~cm}^{-1}$ and $1455 \mathrm{~cm}^{-1}$ using the extinction coefficients reported in literature. ${ }^{[67,68]}$

Thermogravimetric analysis (TG) of the samples after being used in the catalytic tests has been performed by employing Setaram Setsys TGA instrument. The samples were heated up to $800{ }^{\circ} \mathrm{C}$ with a rate of $5{ }^{\circ} \mathrm{C} \mathrm{min}^{-1}$ in air flow.

\section{Catalytic test}

The samples were pressed into wafers and subsequently crushed and sieved to obtain particles in the range 100-200 $\mu \mathrm{m}$. Each catalytic test was performed with $50 \mathrm{mg}$ of catalyst in a fixed bed reactor configuration, with $2.0 \mathrm{~mm}$ inner diameter. Methanol has been added by saturation of $20 \mathrm{ml} / \mathrm{min}$ of $\mathrm{N}_{2}$ by $0.075 \mathrm{ml} / \mathrm{h}$ of methanol, thus giving a WHSV (weight hourly space velocity) of $1.2 \mathrm{~g}$ methanol $/ \mathrm{g}_{\text {zeolite }} / \mathrm{h}$. The product stream was analyzed with an Agilent gas chromatograph equipped with FID detector and automatic sampling (CP-Sil5 column). The catalyst temperature was adjusted to $450{ }^{\circ} \mathrm{C}$ before onset of methanol for all tests, and once the reaction had started the oven temperature was not further changed. Product selectivity was defined as the mole ratio of each product (on $\mathrm{C}_{1}$ basis) referred to the moles of converted methanol. The following products were detected during the reaction: methane, $\mathrm{CO}, \mathrm{CO}_{2}$, light olefins and alkanes $\mathrm{C}_{2}-\mathrm{C}_{4}$ and higher 
hydrocarbons. The column has been calibrated with identification of response factors of the methanol and main products of the reaction.

\section{Coke analysis}

The qualitative analysis of the soluble part of the coke was performed through GC-MS experiment (Shimadzu GCMS-QP2010S). Prior to the analysis the spent catalysts were treated with toluene. The remained powder was dissolved in $40 \%$ HF with subsequent extraction of organic phase by dichloromethane.

\section{Acknowledgements}

This research was performed within the ANR project DIRECTSYNBIOFUEL (ANR-15-CE060004). V.V. acknowledges Thousand Talents program in China.

\section{References}

[1] C. D. Chang, Catal. Rev. Sci. Eng. 1983, 25, 1-118.

[2] J. Q. Chen, A. Bozzano, B. Glover, T. Fuglerud, S. Kvisle, Catal. Today 2005, 106, 103-107.

[3] H. Koempel, W. Liebner, Stud. Surf. Sci. Catal. 2007, 167, 261-267.

[4] J. Cobb, New Zealand Synfuel: The story of the world's first natural gas to gasoline plant, vol. 1, Cobb/Horwood Publications, Auckland, New Zealand, 1995.

[5] B. P. C. Hereijgers, F. Bleken, M. H. Nilsen, S. Svelle, K. P. Lillerud, M. Bjorgen, B. M. Weckhuysen, U. Olsbye, J. Catal. 2009, 264, 77-87.

[6] D. Chen, K. Moljord, A. Holmen, Microporous Mesoposorus Mater. 2012, 164, 239-250.

[7] M. Bjorgen, F. Joensen, M. Spansberger Holm, U. Olsbye, K. P. Lillerud, S. Svelle, Appl. Catal. A 2008, 345, 43-50.

[8] S. Zhang, B. Zhang, Z. Gao, Y. Han, Ind. Eng. Chem. Res. 2010, 49, 2103-2106.

[9] Y. Jin, S. Asaoka, S. Zhang, P. Li, S. Zhao, Fuel Process. Techn. 2013, 115, 34 - 41.

[10] C. D. Chang, C. T.-W. Chu, R. F. Socha, J. Catal. 1984, 86, 289-296.

[11] D. Prinz, L. Riekert, Appl. Catal. 1988, 37, 139-154.

[12] M. Sugimoto, H. Katsuno, K. Takatsu, N. Kawata, Zeolites 1987, 7, 503-507. 
[13] C. Mei, P. Wen, Z. Liu, H. Liu, Y. Wang, W. Yang, Z. Xie, W. Hua, Z. Gao, J. Catal. 2008, 258, 243-249.

[14] F. L. Bleken, S. Chavan, U. Olsbye, M. Boltz, F. Ocampo, B. Louis, Appl. Catal. A 2012, 447-448, 178-185.

[15] J. Liu, C. X. Zhang, Z. H. Shen, W. Hua, Y. Tang, W. Shen, Y. H. Yue, H. L. Xu, Catal. Commun. 2009, 10, 1506-1509.

[16] T. S. Zhao, T. Takemoto, N. Tsubaki, Catal. Commun. 2006, 7, 647-650.

[17] T. Taniguchi, K. Yoneta, S. Nakaoka, Y.Nakasaka, T. Yokoi, T. Tago, T. Masuda, Catal. Lett. 2016 146, 442-451.

[18] U. Olsbye, S. Svelle, K. P. Lillerud, Z. H. Wei, Y. Y. Chen, J. F. Li, J. G. Wang, W. B. Fan, Chem. Soc. Rev. 2015, 44, 7155-7176.

[19] M. Choi, K. Na, J. Kim, Y. Sakamoto, O. Terasaki, R. Ryoo, Nature 2009, 461, 246-249.

[20] A. A. Rownaghi, J. Hedlund, Ind. Eng. Chem. Res. 2011, 50, 11872-11878.

[21] W. Zhijian, W. Wu, G. Li, C. Wang, H. Yang, D. Zhang, Appl. Catal. A 2016, 523, 312-320.

[22] V. Valtchev, L. Tosheva, Chem. Rev. 2013, 113, 6734-6760.

[23] A. Palcic, B. Subotic, V. Valtchev, J. Bronic, CrystEngComm 2013, 15, 5784-5791.

[24] J. Aguado, D. P. Serrano, J. M. Escola, J. M. Rodrigez, Microporous Mesoporous Mater. 2004, 75, 41-49.

[25] Z. Qin, L. Lakiss, L. Tosheva, J.-P. Gilson, A. Vicente, C. Fernandez, V. Valtchev, $A d v$. Funct. Mater. 2014, 24, 257-264.

[26] K. S. Triantafyllidis, L. Nalbandian, P. N. Trikalitis, A. K. Ladavos, T. Mavromoustakos, C. P. Nicolaides, Microporous Mesoporous Mater. 2004, 75, 89-100.

[27] G. Majano, A. Darwiche, S. Mintova, V. Valtchev, Ind. Eng. Chem. Res. 2009, 48, 70847091.

[28] Y. Ni, A. Sun, X. Wua, G. Hai, J. Hua, T. Li, G. Li, J. Coll. Inter. Sci. 2011, 361, 521-526.

[29] F. Deng, Y. Yue, C. Ye, Solid State Nucl. Magn. Reson. 1998, 10, 151-160.

[30] C. P. Grey, A. J. Vega, J. Am. Chem. Soc. 1995, 117, 8232-8242.

[31] D. Massiot, F. Fayon, M. Capron, I. King, S. Le Calvé, B. Alonso, J. O. Durand, B. Bujoli, Z. Gan, G. Hoatson, Magn. Reson. Chem. 2002, 40, 70-76.

[32] S. Sklenak, J. Dedecek, C. Li, B. Wichterlova, V. Gabova, M. Sierka, J. Sauer, Angew. 
Chem. Int. Ed. 2007, 46, 7286-7289.

[33] J. Dedecek, S. Sklenak, C. Li, B. Wichterlova, V. Gabova, J. Brus, M. Sierka, J. Sauer, J. Phys. Chem. C 2009, 113, 1447-1458.

[34] S. M. T. Almutairi, B. Mezari, G. A. Filonenko, P. C. M. M. Magusin, M. S. Rigutto, E. A. Pidko, E. J. M. Hensen, ChemCatChem 2013, 5, 452-466.

[35] A. Omegna, J. A van Bokhoven, R. Prins, J. Phys. Chem. B 2003, 107, 8854-8860.

[36] J. Jiao, J. Kanellopoulos, W. Wang, S. S. Ray, H. Foerster, D. Freude, M. Hunger, Phys. Chem. Chem. Phys. 2005, 7, 3221-3226.

[37] P. N. Kapoor, D. Heroux, R. S. Mulukutla, V. Zaikovskii, K. J. Klabunde, J. Mater. Chem. 2003, 13, 410-414.

[38] S. Jiansirisomboon, K. J. D. MacKenzie, S. G. Roberts, P. S. Grant, J. Eur. Ceram. Soc. 2003, 23, 961-976.

[39] Y. Mathieu, S. Rigolet, V. Valtchev, B. Lebeau, J. Phys. Chem. C 2008, 112, 18384-18392.

[40] T. H. Chen, B. H. Wouters, P. J. Grobet, Eur. J. Inorg. Chem. 2000, 281-285.

[41] J. Chen, T. Chen, N. Guan, J. Wang, Catal. Today 2004, 93-95, 627-630.

[42] E. A. Pidko, S. M. T. Almutairi, B. Mezari, P. C. M. M. Magusin, E. J. M. Hensen, ACS Catal. 2013, 3, 1504-1517.

[43] J.-P. Gilson, G. Edwards, A. W. Peters, K. Rajagopalan, R. F. Wormsbecher, T. J. Roberie, M. P. Shatlock, J. Chem. Soc. Chem. Commun. 1987, 91-92.

[44] P. Sazama, B. Wichterlova, J. Dedecek, Z. Tvaruzkova, Z .Musilova, L. Palumbo, S. Sklenak, O. Gonsiorova, Microporous Mesoporous Mater 2011, 143, 87-96.

[45] M. Smaihi, O. Barida, V. Valtchev, Eur. J. Inorg. Chem. 2003, 24, 4370-4377.

[46] M. V. Landau, D. Tavor, O. Regev, M. L. Kaliya, M. Herskowitz, V. Valtchev, S. Mintova, Chem. Mater. 1999, 11, 2030-2037.

[47] G. Engelhardt, D. Michel, High-resolution solid state NMR of silicates and zeolites, John Wiley \& Sons, New York, 1987.

[48] K. Barbera, F. Bonino, S. Bordiga, T. V. W. Janssen, P. Beato, J. Catal. 2011, 280, 196-205.

[49] Z. Qin, L. Lakiss, J.-P. Gilson, K. Thomas, J.-M. Goupil, C. Fernandez, V. Valtchev, Chem. Mater. 2013, 25, 2759-2766.

[50] M. Trombetta, T. Armaroli, A. Gutièrrez Alejandre, J. Ramirez Solis, G. Busca, Appl. Catal. 
A 2000, 192, 125-136.

[51] I. Kiricsi, C. Flego, G. Pazzuconi, W. O. Parker Jr., R. Millini, C. Perego, G. Bellussi, J. Phys. Chem 1994, 98, 4627-4634.

[52] T. Armaroli, L. J. Simon, M. Digne, T. Montanari, M. Bevilacqua, V. Valtchev, J. Patarin, G. Busca, Appl. Catal. A 2006, 306, 78-84.

[53] F. Ngoye, L. Lakiss, Z. Qin, S. Laforge, C. Canaff, M. Tarighi, V. Valtchev, K. Thomas, A. Vicente, J.-P. Gilson, Y. Pouilloux, C. Fernandez, L. Pinard, J. Catal. 2014, 320, 118-126.

[54] C. Jia, P. Massiani, D. Barthomeuf, J. Chem. Soc. Faraday Trans. 1993, 89, 3659-3665.

[55] M. S. Holm, S. Svelle, F. Joensen, P. Beato, C. H. Christensen, S. Bordinga, M. Bjorgen, Appl. Catal. A 2009, 356, 23-39.

[56] S. Schallmoser, T. Ikuno, M. F. Wagenhofer, R. Kolvenbach, G. L. Haller, M. SanchezSanchez, J. A. Lercher, J. Catal. 2014, 316, 93-102.

[57] T. C. Hoff, R. Thilakaratne, D. W. Gardner, R .C. Brown, J.-Ph. Tessonnier, J. Phys. Chem. C 2016, 120, 20103-20113.

[58] V. V. Ordomsky, V. Y. Murzin, Yu.V. Monakhova, Y. V. Zubavichus, E. E. Knyazeva, N. S. Nesterenko, I. I. Ivanova, Microporous Mesoporous Mater. 2007, 105, 101-110.

[59] M. Maache, A. Janin, J. C. Lavalley, J. F. Joly, E. Benazzi, Zeolites 1993, 13, 419-426.

[60] L. Lakiss, F. Ngoye, C. Canaff, S. Laforge, Y. Poullioux, Z. Qin, M. Tarighi, K. Thomas, V. Valtchev, A. Vicente, L. Pinard, J.-P. Gilson, C. Fernandez, J. Catal. 2015, 328, 165-172.

[61] X. Wu, S. Xu, W. Zhang, J. Huang, J. Li, B. Yu, Y. Wei, Z. Liu, Angew. Chem. Int. Ed. 2017, 56, 9039-9043.

[62] R. Khare, A. Bhan, J. Catal. 2015, 329, 218-228.

[63] D. Mores, J. Kornatowski, U. Olsbye, B. M. Weckhuysen, Chem. Eur. J. 2011, 17, 28742884.

[64] S. Müller, Y. Liu, M. Vishnuvarthan, X. Sun, A. C. van Veen, G. L. Haller, M. SanchezSanchez, J. A. Lercher, J. Catal. 2015, 325, 48-59.

[65] X. Sun, S. Mueller, Y. Liu, H. Shi, G. L. Haller, M. Sanchez-Sanchez, A. C. van Veen, J. A. Lercher, J. Catal. 2014, 317, 185-197.

[66] J. Meusinger, A. Corma, J. Catal. 1996, 159, 353-360.

[67] A. Comas-Vives, M. Valla, C. Copéret, P. Sautet, ACS Cent. Sci. 2015, 1, 313-319. 
[68] C. A. Emeis, J. Catal. 1993, 141, 347-354.

[69] T. Onfroy, G. Clet, M. Houalla, Microporous Mesoporous Mater. 2005, 82, 99-104. 


\section{TABLE OF CONTENTS}

High temp. crystal. Low temp. crystal.
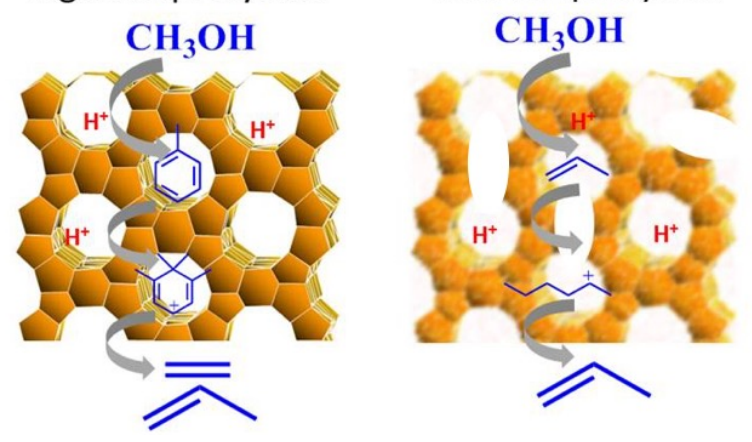

Decrease of ZSM-5 crystallization temperature led to decreased strength of acid sites with increased selectivity to propylene in MTO. 